Article

\title{
A Novel Antibacterial Component and the Mechanisms of an Amaranthus tricolor Leaf Ethyl Acetate Extract against Acidovorax avenae subsp. citrulli
}

\author{
Ya Zhang ${ }^{1}{ }^{(D}, K_{e}$ Gao $^{1}$, Chong Wang ${ }^{2, *}$ and Shuangqing Liu ${ }^{1, *}$ \\ 1 College of Plant Protection, Hunan Agricultural University, Changsha 410128, China; \\ zhangya230@126.com (Y.Z.); gaoke@stu.hunau.edu.cn (K.G.) \\ 2 College of Bioscience and Biotechnology, Hunan Agricultural University, Changsha 410128, China \\ * Correspondence: wangchong@hunau.edu.cn (C.W.); liushuangqing@hunau.edu.cn (S.L.); \\ Tel.: +86-0731-8461-8163 (S.L.)
}

Citation: Zhang, Y.; Gao, K.; Wang, C.; Liu, S. A Novel Antibacterial Component and the Mechanisms of an Amaranthus tricolor Leaf Ethyl Acetate Extract against Acidovorax avenae subsp. citrulli. Int. J. Mol. Sci. 2022, 23, 312. https://doi.org/ 10.3390/ijms23010312

Academic Editor: Hideo Nakashita

Received: 29 November 2021

Accepted: 25 December 2021

Published: 28 December 2021

Publisher's Note: MDPI stays neutral with regard to jurisdictional claims in published maps and institutional affiliations.

Copyright: (C) 2021 by the authors. Licensee MDPI, Basel, Switzerland. This article is an open access article distributed under the terms and conditions of the Creative Commons Attribution (CC BY) license (https:// creativecommons.org/licenses/by/ $4.0 /)$.
Abstract: The aim of the present investigation was to determine the active ingredients in Amaranthus tricolor L. leaves and develop a biological pesticide. Organic solvent extraction, column chromatography, liquid chromatography, ODS-C18 reverse elution, Sephadex LH-20 gel filtration, H spectrum, and $\mathrm{C}$ spectrum were used to isolate the pure product for an assessment of the agricultural activity and bacteriostatic mechanisms. The results showed that the activity of the crude extract following carbon powder filtration was 1.63-fold that of the non-filtered extract. Further isolation was performed to obtain two pure products, namely, hydroxybenzoic acid (HBA) and benzo[b]furan-2-carboxaldehyde (BFC), and their molecular formulas and molecular weights were $\mathrm{C}_{7} \mathrm{H}_{6} \mathrm{O}_{3}$ and 138.12 , and $\mathrm{C}_{9} \mathrm{H}_{6} \mathrm{O}_{2}$ and 146.12, respectively. Our study is the first to determine that HBA has bacteriostatic activity (MIC $125 \mu \mathrm{g} / \mathrm{mL}$ ) and is also the first to isolate BFC from A. tricolor. The ultrastructure observation results showed that HBA caused the bacteria to become shriveled, distorted, and deformed, as well as exhibit uneven surfaces. After HBA treatment, 70 differentially expressed metabolites were detected in the bacteria, of which 9 were downregulated and 61 were upregulated. The differentially expressed metabolites were mainly strigolactones, organic acids and derivatives, fatty acids, benzene and substituted benzene derivatives, amino acids and associated metabolites, and alcohols and amines. Among all of the downregulated differentially expressed metabolites, MEDP1280 was the most critical, as it participates in many physiological and biochemical processes. The enrichment analysis showed that the differentially expressed metabolites mainly participate in tyrosine metabolism, biosynthesis of amino acids, cysteine and methionine metabolism, and arginine and proline metabolism. Additionally, HBA was found to disrupt cell membrane permeability and integrity, causing the leakage of substances and apoptosis. The physiological and biochemical test results showed that HBA could increase the pyruvate levels in bacteria but could decrease the activities of respiratory enzymes (malate dehydrogenase (MDH) and NADH oxidase) and antioxidant enzymes (superoxide dismutase (SOD) and glutathione peroxidase (GSH-PX)). Inverse molecular docking was used to study the binding between HBA and respiratory and antioxidant enzymes. The results showed that HBA could bind to MDH, NADH oxidase, SOD, and GSH-PX, suggesting that these enzymes may be the effector targets of HBA. Conclusion: The optimal active ingredient in A. tricolor that can inhibit Acidovorax avenae subsp. citrulli was identified as HBA. HBA mainly disrupts the cell membrane, damages the metabolic system, and inhibits respiration and antioxidant enzyme activity to control bacterial growth. These results provide a reference for the further development of biological pesticides.

Keywords: Amaranthus tricolor; bacteriostatic component; identification; ultrastructure observation; metabolome; enzymatic activity; molecular docking 


\section{Introduction}

Amaranthus tricolor L. is a dicotyledonous herb that is widely cultivated in tropical and temperate regions [1]. It exhibits strong stress resistance, including drought and barren land resistance, grows easily, requires little time investment for agricultural production, and has a high survival rate [2,3]. It also has high nutritional value, being rich in vitamins and minerals, and is mainly consumed as a leafy vegetable [4,5]. Additionally, A. tricolor has a high red pigment content, and its pigments are typically extracted industrially to prepare food additives [6]. A study by Yustiati et al. showed that A. tricolor can be used as an animal feed to increase production efficiency in animals [7]. In addition, many studies have found that amaranth plants have medicinal value, and A. tricolor exhibits in vivo anti-cancer activity. Jayaprakasam et al. showed that $A$. tricolor has exceptionally good tumor control results [8], and A. tricolor has been found to decrease glucose and labor pain. Rahmatullah et al. found that $A$. tricolor can be used as an antihyperglycemic and antinociceptive drug [9]. Other studies have also demonstrated that $A$. tricolor has antioxidant effects. For instance, Khandaker (2008) and Alam (2013) found that $A$. tricolor can be used as an antioxidant to treat refractory diseases $[10,11]$. Khanam et al. found that the phenol content of $A$. tricolor is intimately associated with its antioxidant capacity [12]. Another study also found that $A$. tricolor has hepatoprotective effects. Al-Dosari et al. showed that $A$. tricolor extract can decrease liver disease-related markers such as glutamate oxaloacetate transaminase (GOT), alkaline phosphatase (ALP), bilirubin, and cholesterol, and it can be used as a natural hepatoprotectant for treating liver diseases [13]. Amaranthus tricolor can also prevent obesity, of which $50 \mu \mathrm{g} / \mathrm{mL}$ EERS showed strong prophylactic effects in diet-induced obesity in zebrafish [14]. Many studies have shown that Amaranthus plants have good inhibitory effects on contaminating bacteria and fungi in foodstuffs. Pulipati et al. found that the methanol extract of A. tricolor exhibited the best inhibitory effect on Escherichia coli, followed by ethyl acetate, chloroform, and petroleum ether extracts [15]. Oh et al. [16] found that the chloroform extract of Amaranthus lividus has high inhibitory effects on foodborne bacteria, such as Listeria monocytogenes, Salmonella spp., and Staphylococcus aureus. AbdAziz et al. [17] also found that the active ingredients of Amaranthus mangostanus have strong inhibitory effects on common foodborne bacteria. Lina [18] and Lyapkova [19] discovered that Amaranthus hypochondriacus and Amaranthus caudatus contain many microbiostatic substances that act against saprophytic fungi. However, there are very few studies on the agricultural value of A. tricolor, and its potential active substances remain to be discovered and utilized. As there are differences in the pathogenesis between foodborne bacterial and fungal pathogens, and agricultural bacterial and fungal pathogens, we wondered whether $A$. tricolor also exhibits inhibitory effects on agricultural bacterial and fungal pathogens, as it does show inhibitory effects on foodborne bacterial and fungal pathogens. Studies have found that $A$. tricolor exerts numerous inhibitory effects on many plant pathogens, but it is not clear what the active substances are. It is also unclear whether this substance is a novel compound or a known compound or whether it has a novel structure. This limits the development and application of A. tricolor [20]. To address this, Acidovorax avenae subsp. citrulli, a plant quarantine bacterium, was used as an indicator bacterium on an ethyl acetate leaf extract of $A$. tricolor. The extract was filtered with activated carbon to remove pigment prior to column chromatography. Thin-layer chromatography (TLC), ODS-C18 reverse elution, Sephadex LH-20 gel filtration, and nuclear magnetic resonance (NMR) were used for isolation and purification, followed by structure identification. Ultrastructure observation, metabolomics analysis, physiological and biochemical tests, and molecular docking techniques were used to study the effector mechanisms of critical bacteriostatic molecules in order to discover lead compounds with novel structures as well as determine bacteriostatic molecular targets to provide a theoretical basis for further development of biological pesticides. 


\section{Results}

\subsection{Bacteriostatic Activity of the Activated Carbon Chromatography Eluate of A. tricolor}

As shown in Figure 1, the zone of inhibition of the $A$. tricolor ester extract that underwent activated carbon chromatography and did not undergo activated carbon chromatography was 4.45 and $2.73 \mathrm{~cm}$, respectively. The zone of inhibition of the $A$. tricolor ester extract that underwent activated carbon chromatography was 1.63-fold that of the $A$. tricolor ester extract that did not undergo activated carbon chromatography. This showed that activated carbon chromatography enhanced the inhibitory effects of the $A$. tricolor ester extract on A. avenae subsp. citrulli and that 'impurities' were adsorbed on the activated carbon, and hence, the activated carbon had a purification role toward the extract.

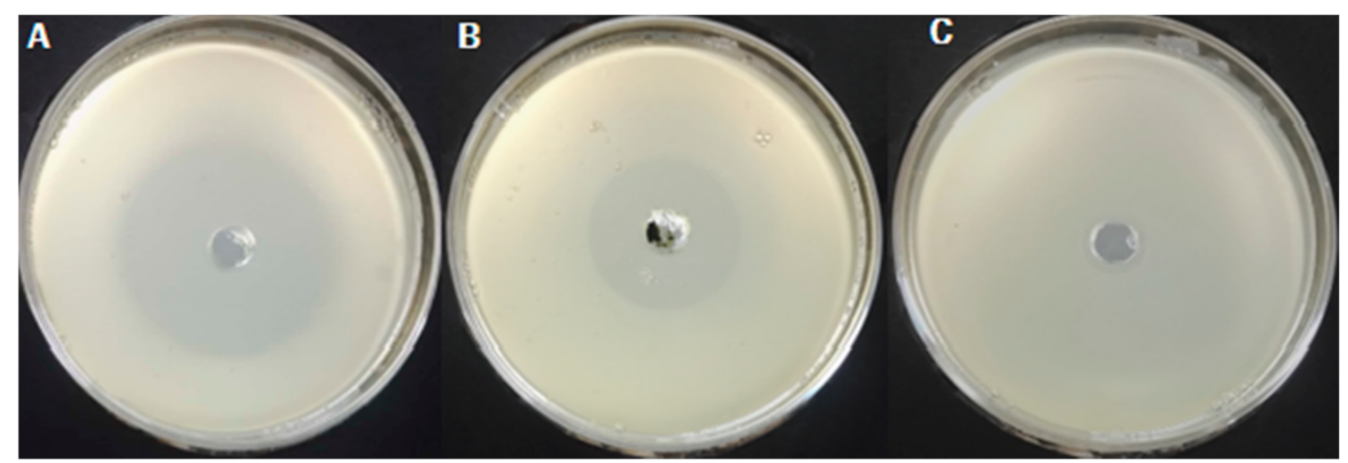

Figure 1. Antibacterial activity of ethyl acetate extract before and after elution by carbon column chromatography. (A) Treated by carbon column; (B) not treated by carbon column; (C) blank control.

\subsection{A. tricolor Ester Extract Isolation and Purification}

Trichloromethane: methanol (1:0, 9:1, 4:1, 7:3, 3:2, 0:1) was used for gradient elution of the silica gel column. Collection was performed every $250 \mathrm{~mL}$, and 87 elution bottles were collected. After testing, 20 fractions were combined, and activity testing was performed to obtain nine bacteriostatic fractions. An ODS-18 reverse-phase silica gel column was used, and methanol was used for gradient elution. Collection was performed every $100 \mathrm{~mL}$, and 83 elution bottles were collected. After testing and combining, seven fractions were obtained, and activity testing was performed to obtain one bacteriostatic fraction. This bacteriostatic fraction underwent Sephadex LH-20 silica gel column separation, and 100\% methanol was used for elution. Collection was performed every $5 \mathrm{~mL}$, and 54 elution bottles were collected. After testing, compound 1 with a purity of $95.68 \%$ (52.60 mg) and compound 1 with a purity of $95.73 \%$ (33.90 mg) were collected and named compounds 1 and 2.

\subsection{Structural Identification of Pure Products}

Compound 1: yellowish-white needle crystals (methanol), molecular formula was $\mathrm{C}_{7} \mathrm{H}_{6} \mathrm{O}_{3}$, and molecular weight was 138.12. $1 \mathrm{H}$ NMR (500 MHz, MeOD) $\delta 7.80-7.73$ (m, $82 \mathrm{H}), 6.74-6.67(\mathrm{~m}, 81 \mathrm{H}), 4.83(\mathrm{~s}, 135 \mathrm{H}), 3.61-3.50(\mathrm{~m}, 4 \mathrm{H}), 3.21(\mathrm{dt}, \mathrm{J}=3.3,1.7 \mathrm{~Hz}$, $35 \mathrm{H}), 1.18$ (s, $7 \mathrm{H}), 0.86-0.76$ (m, $2 \mathrm{H}), 0.03-0.06$ (m, $11 \mathrm{H}) ; 13 \mathrm{C}$ NMR (126 MHz, MeOD) $\delta 170.94$ (s), 162.96 (s), 132.89 (s), 123.89 (s), 115.91 (s), 49.52 (s), 49.26 (d, J = 21.4 Hz), 49.01 (s), 48.84 (s), 48.67 (s), 48.50 (s). The above data were consistent with that reported by Chen et al. [21]. Therefore, this compound was identified as 4-hydroxybenzoic acid (HBA) (Figure 2).

Compound 2: yellowish-white powder (methanol), molecular formula was $\mathrm{C}_{9} \mathrm{H}_{6} \mathrm{O}_{2}$, and molecular weight was 146.14. ${ }^{1} \mathrm{H}$ NMR (500 MHz, MeOD) $\delta 7.66(\mathrm{~d}, \mathrm{~J}=16.2 \mathrm{~Hz}, 3 \mathrm{H})$, $6.12(\mathrm{~d}, \mathrm{~J}=16.1 \mathrm{~Hz}, 3 \mathrm{H}), 5.82(\mathrm{~s}, 3 \mathrm{H}), 5.66(\mathrm{~s}, 3 \mathrm{H}), 5.41-5.30(\mathrm{~m}, 2 \mathrm{H}), 4.83(\mathrm{~s}, 94 \mathrm{H})$, $3.84(\mathrm{dd}, \mathrm{J}=17.2,9.3 \mathrm{~Hz}, 2 \mathrm{H}), 3.52(\mathrm{~d}, \mathrm{~J}=26.9 \mathrm{~Hz}, 4 \mathrm{H}), 3.52-3.37$ (m, $1 \mathrm{H}), 3.21$ (dt, J = 3.3, $1.6 \mathrm{~Hz}, 21 \mathrm{H}), 2.62(\mathrm{t}, \mathrm{J}=6.4 \mathrm{~Hz}, 18 \mathrm{H}), 2.51-1.89(\mathrm{~m}, 90 \mathrm{H}), 1.82(\mathrm{dd}, \mathrm{J}=13.3,4.7 \mathrm{~Hz}, 11 \mathrm{H})$, $1.62(\mathrm{~d}, \mathrm{~J}=13.3 \mathrm{~Hz}, 2 \mathrm{H}), 1.57-1.34(\mathrm{~m}, 50 \mathrm{H}), 1.34-1.05(\mathrm{~m}, 76 \mathrm{H}), 1.07$ (d, J = 17.8 Hz, $1 \mathrm{H})$, 1.11-0.99 (m, $5 \mathrm{H}), 0.95(\mathrm{~d}, \mathrm{~J}=17.9 \mathrm{~Hz}, 19 \mathrm{H}), 0.81(\mathrm{t}, \mathrm{J}=7.0 \mathrm{~Hz}, 8 \mathrm{H}), 0.00(\mathrm{~s}, 1 \mathrm{H}) ;{ }^{13} \mathrm{C}$ 
NMR (126 MHz, MeOD) $848.45-47.67$ (m), 47.60 (s), 47.42 (s), 47.25 (s), 47.08 (s). The above data were consistent with the literature [22]. Therefore, the compound was identified as benzo[b]furan-2-carboxaldehyde (BFC) (Figure 3).
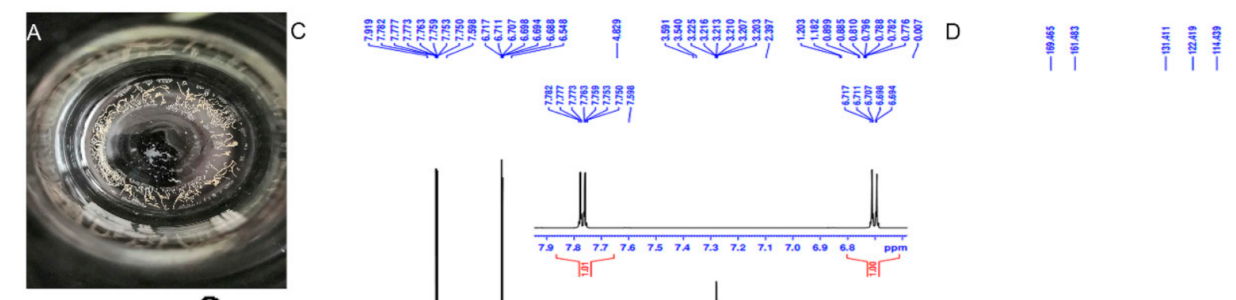<smiles>O=C(O)c1ccc(O)cc1</smiles>

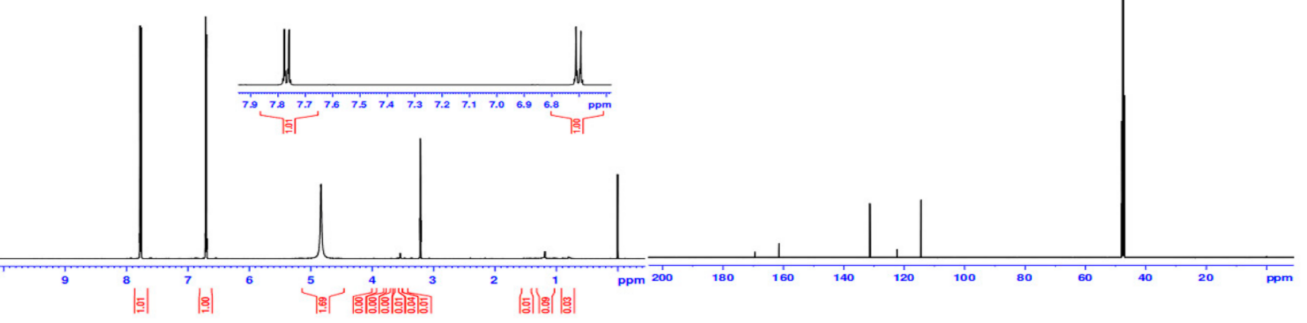

Figure 2. Morphology and structure identification of HBA. Note: (A) physical state; (B) structural formula; (C) ${ }^{1} \mathrm{H}-\mathrm{NMR}$ diagram of HBA (500 MHz, MeOD); (D) ${ }^{13} \mathrm{C}-\mathrm{NMR}$ of HBA (126 MHz, MeOD).
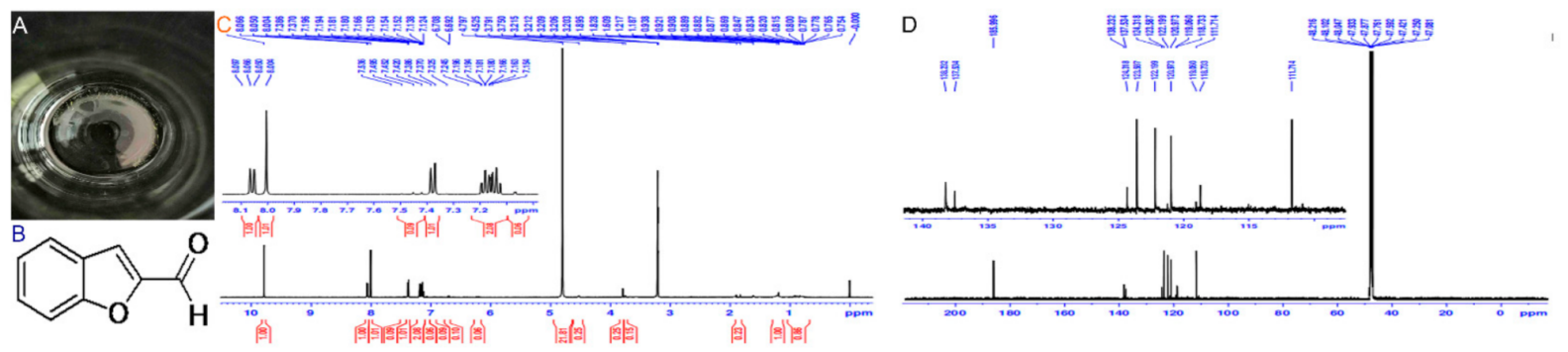

Figure 3. Morphology and structure identification of BFC. Note: (A) physical state; (B) structural formula; (C) ${ }^{1} \mathrm{H}-\mathrm{NMR}$ diagram of BFC (500 MHz, MeOD); (D) ${ }^{13} \mathrm{C}-\mathrm{NMR}$ of BFC (126 MHz, MeOD).

\subsection{Virulence Measurement of A. tricolor Active Ingredients}

From Table 1, it can be seen that HBA had inhibitory effects on A. avenae subsp. citrulli, and the zone of inhibition was $2.29 \mathrm{~cm}$, which was comparable to the positive control and the difference was not significant $(p>0.05)$. BFC did not have any bacteriostatic effects on $A$. avenae subsp. citrulli, and the zone of inhibition was lower than the positive control (Table 1). Two-fold dilution in a 96-well plate was used for MIC measurement of HBA. The results indicated that the MIC of HBA towards A. avenae subsp. citrulli was $125 \mu \mathrm{g} / \mathrm{mL}$, thus showing potent bacteriostatic activity with potential for further research and development (Figure 4).

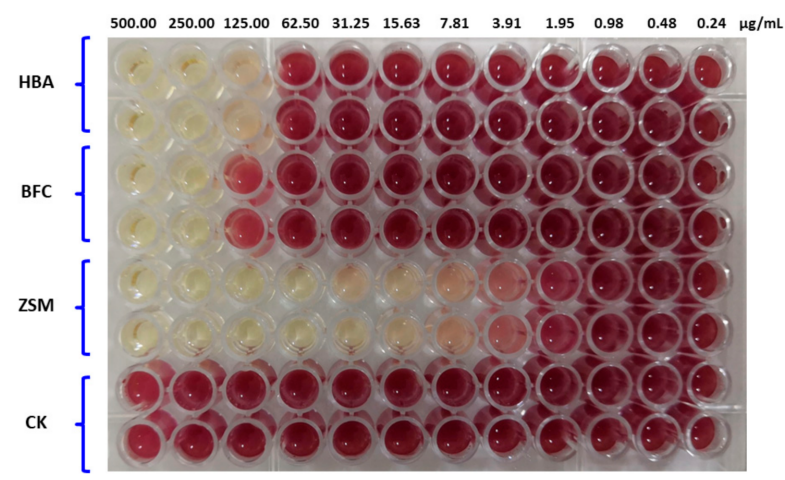

Figure 4. Determination of MIC value of novel fungicide HBA against A. avenae subsp. citrulli. Note: HBA: 4-hydroxybenzoic acid; BFC: benzo[b]furan-2-carboxaldehyde; ZSM: zhongshengmycin; CK: control. 
Table 1. Inhibition effect of three fungicides against $A$. avenae subsp. citrulli.

\begin{tabular}{cc}
\hline \multirow{2}{*}{ Compound } & Inhibition Zone Diameter (cm) \\
\cline { 2 - 2 } & Average Value \\
\hline HBA & $2.29 \pm 0.05^{\mathrm{a}}$ \\
BFC & $0.54 \pm 0.02^{\mathrm{b}}$ \\
Zhongshengmycin (positive control) & $2.23 \pm 0.01^{\mathrm{a}}$ \\
\hline
\end{tabular}

Note: Different lowercase letters indicate significant differences at the $p<0.05$ level.

\subsection{Ultrastructure Observation of Bacteria Inhibited by HBA}

Under $5000 \times$ magnification, the untreated bacteria appeared rod-shaped, filled, and rounded, with clear edges, neatly stacked and arranged, and consistent in size, and ruptures and distortion were absent (Figure 5A1,B1). The HBA-treated bacteria were shriveled, wrinkled, distorted, and deformed, and the bacterial surface was uneven and even ruptured (Figure 5A2,B2). Under 10,000 $\times$ magnification, the untreated bacteria had clear edges and smooth surfaces, protrusions and depressions were absent, and many filaments were present (Figure 5C1,D1). The HBA-treated bacteria had a coarse and uneven surface and inconsistent depth, and some bacteria were ruptured or disintegrated (Figure 5C2,D2). This demonstrated that HBA could cause bacterial deformation.

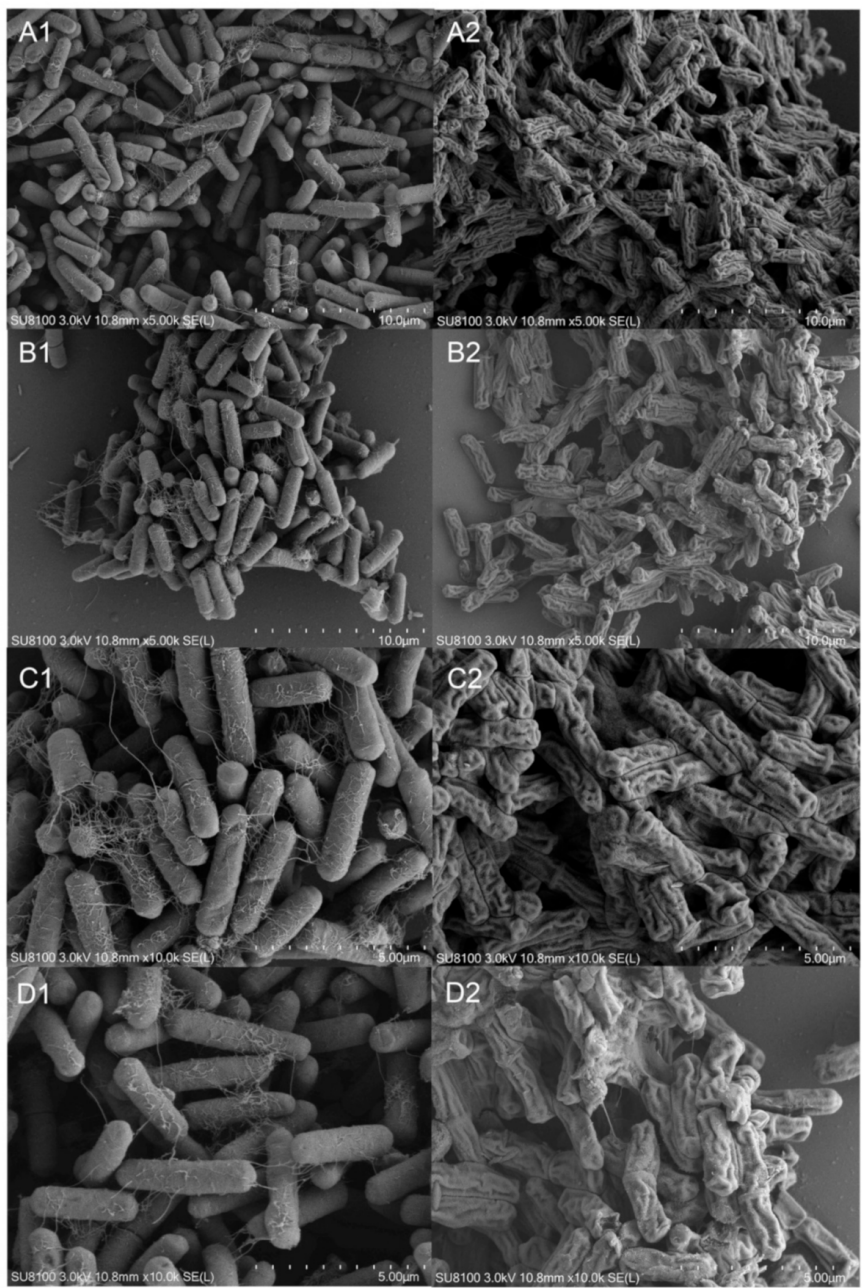

Figure 5. Morphology and structure alterations of HBA-treated A. avenae subsp. citrulli observed by SEM. Note: (A1,B1): The control A. avenae subsp. citrulli with 5000 times. (C1,D1): The control A. avenae subsp. citrulli with 10,000 times. (A2,B2): The treated A. avenae subsp. citrulli with 5000 times $(125 \mu \mathrm{g} / \mathrm{mL})$. (C2,D2): The treated A. avenae subsp. citrulli with 10,000 times $(125 \mu \mathrm{g} / \mathrm{mL})$. 


\subsection{Effects of HBA on the Bacterial Metabolome}

Orthogonal partial least squares-discriminant analysis (OPLS-DA) removes systemic differences that are unrelated to groups to screen for differentially expressed metabolites and achieve maximum separation. The prediction parameters of the evaluation model include $R^{2} X, R^{2} Y$, and $Q^{2}$, of which $R^{2} X$ and $R^{2} Y$ represent the explanatory power of the constructed model on the $X$ and $Y$ matrices and $Q^{2}$ represents the predictive capacity of the model. The closer these markers are to 1 , the more reliable the model. The model is considered to be effective when $Q^{2}>0.5$. An S-plot was used to identify differentially expressed compounds related to the groupings. The supervised OPLS-DA was performed on the treatment group and control group. The results showed that the inter-group differences were significant, whereas the intra-group differences were not significant (Figure 6A). From Figure $6 \mathrm{~B}$, it can be seen that when OPLS-DA was performed, the OPLS-DA score charts of the treatment group and control group were $R^{2} X=0.429, R^{2} Y=1$, and $Q 2=0.641$, showing that this model has good accuracy and predictive power. The corresponding S-plot shows the most related metabolites in the two groups (Figure 6C).

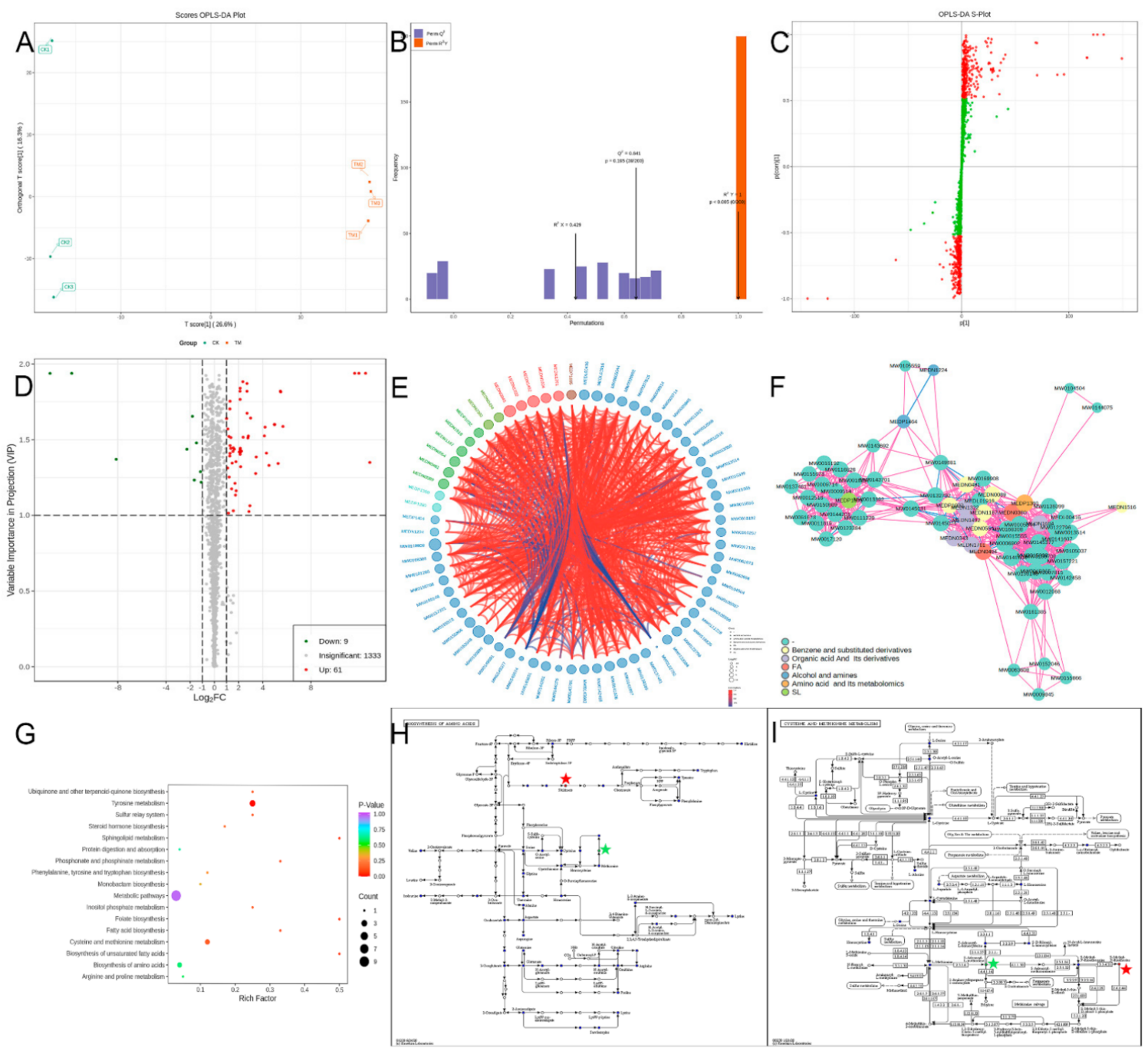

Figure 6. Metabolite's analysis of HBA-treated A. avenae subsp. citrulli by LC-MS/MS. Notes: (A): OPLS-DA score plot; (B): OPLS-DA verification diagram; (C): OPLS-DA S-plot; (D): difference metabolite volcano map; (E): difference metabolites and dazzle diagram; (F): difference metabolite network diagram; $(\mathbf{G})$ : difference metabolites KEGG enrichment; $(\mathbf{H})$ : biosynthesis of amino acids difference metabolites KEGG pathway; (I): cysteine and methionine difference metabolites KEGG pathway. 
There were 70 differentially expressed metabolites in the HBA-treated bacteria, of which 9 metabolites were downregulated and 61 metabolites were upregulated (Table 2, Figure 6D). These differentially expressed metabolites may be potential biological targets and include strigolactones, organic acids and derivatives, fatty acids, benzene and substituted benzene derivatives, amino acids and associated metabolites, alcohols and amines, and other metabolites (Figure 6E). The correlation of differentially expressed metabolites was further studied, and the results showed that most metabolites had a close relationship and only a few metabolites did not have a close relationship (Figure 6E). This shows that many metabolites have synergistic or inter-regulatory relationships and play similar or identical roles in life activities. From the network correlation of differentially expressed metabolites, it can be seen that most differentially expressed metabolites had good network correlation, with correlations being present between different metabolites and only a few metabolites exhibiting poor correlations. 3,7,4'-Trihydroxyflavone (MW0132792), ancistrocladine (MW145074), aminopentol (MW0145031), 5'-S-methyl-5' thioinosine (MW0143701), and 5'-oxoinosine (MW0143692) acted as links in many metabolite relationships, of which 3,7,4'-trihydroxyflavone (MW0132792) downregulation affected many metabolites (Figure 6F). Hence, there are synergistic or inter-regulatory relationships between these metabolites. Differentially expressed metabolites interact with each other to form different pathways. The Kyoto Encyclopedia of Genes and Genomes (KEGG) metabolic pathways are indicated in Figure $6 \mathrm{H}$. Changes in metabolic pathways such as tyrosine metabolism, biosynthesis of amino acids, cysteine and methionine metabolism, arginine and proline metabolism, sulfur relay system, inositol phosphate metabolism, and phosphonate and phosphinate metabolism occurred after the bacteria were treated with $\mathrm{HBA}$, and changes were the greatest in the biosynthesis of amino acids and cysteine and methionine metabolism. Disruption of these metabolic pathways inhibited bacterial growth (Figure 6I). This showed that HBA could alter metabolic pathways to inhibit bacterial growth and control bacteria. In-depth analysis of the metabolite changes in metabolic pathways that were greatly affected (tyrosine metabolism, biosynthesis of amino acids, cysteine and methionine metabolism) by HBA showed that 2,5-dihydroxy benzoic acid (MEDN0089), phenol (MEDL01916), and 2-(4-Hydroxyphenyl) ethanol (MEDN0554) in tyrosine metabolism were upregulated, which may be related to drug resistance. S-AdenosylL-methionine (MEDP1280) in the biosynthesis of amino acids was downregulated, which may be an HBA target, and S-adenosyl-L-methionine (MEDP1280) in cysteine and methionine metabolism was also downregulated, whereas MW0143701 was regulated, which may be related to HBA resistance. Obviously, S-adenosyl-L-methionine (MEDP1280) was also downregulated in other metabolic pathways, showing that this substance plays important roles in many metabolic pathways.

Table 2. Significantly different metabolites putatively identified by UPLC-MS/MS.

\begin{tabular}{|c|c|c|c|c|c|}
\hline Number & Index & Formula & Compounds & Log2FC & Type \\
\hline 1 & MW0152046 & $\mathrm{C}_{22} \mathrm{H}_{27} \mathrm{NO}_{5}$ & Kreysigine & 12.87 & up \\
\hline 2 & MW0169908 & $\mathrm{C}_{24} \mathrm{H}_{48} \mathrm{O}_{2}$ & Tetracosanoic acid & 12.52 & up \\
\hline 3 & MEDN1492 & $\mathrm{C}_{8} \mathrm{H}_{8} \mathrm{O}_{3}$ & (R)-(-)-Mandelic acid & 11.96 & up \\
\hline 4 & MEDN0343 & $\mathrm{C}_{7} \mathrm{H}_{10} \mathrm{O}_{5}$ & Shikimic Acid & 11.61 & up \\
\hline 5 & MEDL01916 & $\mathrm{C}_{6} \mathrm{H}_{6} \mathrm{O}$ & Phenol & 5.68 & up \\
\hline 6 & MEDN1167 & $\mathrm{C}_{7} \mathrm{H}_{6} \mathrm{O}_{3}$ & 4-Hydroxybenzoic Acid & 5.49 & up \\
\hline 7 & MEDN0554 & $\mathrm{C}_{8} \mathrm{H}_{10} \mathrm{O}_{2}$ & 2-(4-Hydroxyphenyl)ethanol & 5.47 & up \\
\hline 8 & MW0155866 & $\mathrm{C}_{13} \mathrm{H}_{19} \mathrm{~N}_{5} \mathrm{O}_{4}$ & Pro Gly His & 5.28 & up \\
\hline 9 & MEDN0089 & $\mathrm{C}_{7} \mathrm{H}_{6} \mathrm{O}_{4}$ & 2,5-Dihydroxy Benzoic Acid & 4.98 & up \\
\hline 10 & MEDN1224 & $\mathrm{C}_{12} \mathrm{H}_{24} \mathrm{O}_{17} \mathrm{P}_{2}$ & Bis(1-inositol)-3,1'-phosphate 1-phosphate & -1.66 & down \\
\hline 11 & MEDN0481 & $\mathrm{C}_{7} \mathrm{H}_{6} \mathrm{O}_{4}$ & 2,4-Dihydroxy Benzoic Acid & 4.98 & up \\
\hline 12 & MEDN1322 & $\mathrm{C}_{7} \mathrm{H}_{6} \mathrm{O}_{4}$ & 2,3-Dihydroxybenzoic acid & 4.98 & up \\
\hline 13 & MEDN1701 & $\mathrm{C}_{7} \mathrm{H}_{6} \mathrm{O}_{4}$ & 3,5-Dihydroxybenzoic acid & 4.98 & up \\
\hline 14 & MW0009845 & $\mathrm{C}_{16} \mathrm{H}_{22} \mathrm{ClN}_{3} \mathrm{O}$ & Tebuconazole & 4.52 & up \\
\hline 15 & MEDL00416 & $\mathrm{C}_{12} \mathrm{H}_{24} \mathrm{O}_{3}$ & 3-Hydroxydodecanoic acid & 4.31 & up \\
\hline
\end{tabular}


Table 2. Cont.

\begin{tabular}{|c|c|c|c|c|c|}
\hline Number & Index & Formula & Compounds & Log2FC & Type \\
\hline 16 & MW0013514 & $\mathrm{C}_{10} \mathrm{H}_{20} \mathrm{O}_{3}$ & 2-Hydroxydecanoate & 4.20 & up \\
\hline 17 & MEDP1280 & $\mathrm{C}_{15} \mathrm{H}_{22} \mathrm{~N}_{6} \mathrm{O}_{5} \mathrm{~S}$ & S-Adenosyl-L-Methionine & -1.09 & down \\
\hline 18 & MW0105037 & $\mathrm{C}_{10} \mathrm{H}_{20} \mathrm{O}_{3}$ & 3-Hydroxycapric acid & 4.14 & up \\
\hline 19 & MEDP1464 & $\mathrm{C}_{13} \mathrm{H}_{13} \mathrm{~N}_{3}$ & 1,3-Diphenylguanidine & -2.27 & down \\
\hline 20 & MEDN1604 & $\mathrm{C}_{14} \mathrm{H}_{28} \mathrm{O}_{3}$ & 3-hydroxy-tetradecanoic acid & 3.47 & up \\
\hline 21 & MW0015365 & $\mathrm{C}_{16} \mathrm{H}_{26} \mathrm{O}_{3}$ & 8R-Hydroxy-4Z,6E,10Z-hexadecatrienoic acid & 3.42 & up \\
\hline 22 & MW0111229 & $\mathrm{C}_{18} \mathrm{H}_{39} \mathrm{~N}$ & n-Octadecylamine & 3.00 & up \\
\hline 23 & MW0122796 & $\mathrm{C}_{18} \mathrm{H}_{13} \mathrm{ClFN}_{3} \mathrm{O}$ & Alpha-hydroxymidazolam & 2.94 & up \\
\hline 24 & MW0141607 & $\mathrm{C}_{15} \mathrm{H}_{24} \mathrm{~N}_{2} \mathrm{O}_{2}$ & 17-Hydroxylupanine & 2.86 & up \\
\hline 25 & MW0145377 & $\mathrm{C}_{15} \mathrm{H}_{26} \mathrm{~N}_{8} \mathrm{O}_{5}$ & Arg His Ser & 2.81 & up \\
\hline 26 & MW0158148 & $\mathrm{C}_{25} \mathrm{H}_{28} \mathrm{~N}_{4} \mathrm{O}_{6}$ & Trp Glu Phe & 2.77 & up \\
\hline 27 & MW0141608 & $\mathrm{C}_{22} \mathrm{H}_{32} \mathrm{O}_{3}$ & $\begin{array}{l}\text { 17-keto-7(Z),10(Z),13(Z),15(E),19(Z)- } \\
\text { Docosapentaenoic Acid }\end{array}$ & 2.70 & up \\
\hline 28 & MW0006902 & $\mathrm{C}_{13} \mathrm{H}_{13} \mathrm{OP}$ & Diphenylmethylphosphine oxide & 2.70 & up \\
\hline 29 & MEDN0380 & $\mathrm{C}_{16} \mathrm{H}_{30} \mathrm{O}_{2}$ & $\operatorname{FFA}(16: 1)$ & 2.70 & up \\
\hline 30 & MW0063608 & $\mathrm{C}_{30} \mathrm{H}_{48} \mathrm{O}_{2}$ & Soyasapogenol C;Sapogenol C & 2.38 & up \\
\hline 31 & MEDN0494 & $\mathrm{C}_{20} \mathrm{H}_{32} \mathrm{O}_{4}$ & 8,15 -Dihete & 2.35 & up \\
\hline 32 & MW0061673 & $\mathrm{C}_{18} \mathrm{H}_{40} \mathrm{NO}_{6} \mathrm{P}$ & $\begin{array}{l}\text { Phytosphingosine-1-P } \\
\text { (1S)-3-[(Z)-2-[(1R,7aR)-7a-methyl-1-[(2R)-6- }\end{array}$ & 2.24 & up \\
\hline 33 & MW0161385 & $\mathrm{C}_{27} \mathrm{H}_{44} \mathrm{O}$ & $\begin{array}{l}\text { methylheptan-2-yl]-1,2,3,3a,6,7- } \\
\text { hexahydroinden-4-yl]ethenyl]-4- } \\
\text { methylcyclohex-3-en-1-ol }\end{array}$ & 2.17 & up \\
\hline 34 & MW0011819 & $\mathrm{C}_{17} \mathrm{H}_{33} \mathrm{O}_{7} \mathrm{P}$ & 1-(9Z-tetradecenoyl)-glycero-3-phosphate & 2.17 & up \\
\hline 35 & MW0009514 & $\mathrm{C}_{23} \mathrm{H}_{31} \mathrm{NO}_{2}$ & Proadifen & 2.14 & up \\
\hline 36 & MW0168308 & $\mathrm{C}_{21} \mathrm{H}_{30} \mathrm{O}_{4}$ & [10]-Dehydrogingerdione & 2.13 & up \\
\hline 37 & MW0150989 & $\mathrm{C}_{17} \mathrm{H}_{27} \mathrm{~N}_{5} \mathrm{O}_{6}$ & His Leu Glu & 2.13 & up \\
\hline 38 & MW0009714 & $\mathrm{C}_{25} \mathrm{H}_{37} \mathrm{NO}_{4}$ & Salmeterol & 2.13 & up \\
\hline 39 & MEDP1032 & $\mathrm{C}_{7} \mathrm{H}_{6} \mathrm{O}_{2}$ & Salicylaldehyde & 2.13 & up \\
\hline 40 & MW0104504 & $\mathrm{C}_{3} \mathrm{H}_{8} \mathrm{NO}_{5} \mathrm{P}$ & 2-Amino-3-phosphonopropionic acid & -1.82 & down \\
\hline 41 & MW0145031 & $\mathrm{C}_{22} \mathrm{H}_{47} \mathrm{NO}_{5}$ & Aminopentol; AP1 & 2.12 & up \\
\hline 42 & MW0105559 & $\mathrm{C}_{6} \mathrm{H}_{12} \mathrm{~N}_{2} \mathrm{O}_{4}$ & Ala-Ser & -1.15 & down \\
\hline 43 & MW0016192 & $\mathrm{C}_{25} \mathrm{H}_{37} \mathrm{NO}_{4}$ & Bimatoprost & 2.06 & up \\
\hline 44 & MW0007815 & $\mathrm{C}_{17} \mathrm{H}_{20} \mathrm{~N}_{2} \mathrm{O}$ & Michler's ketone & 1.80 & up \\
\hline 45 & MW0017120 & $\mathrm{C}_{26} \mathrm{H}_{34} \mathrm{O}_{6}$ & Cinobufagin & 1.78 & up \\
\hline 46 & MW0012068 & $\mathrm{C}_{21} \mathrm{H}_{30} \mathrm{O}_{3}$ & 11a-Hydroxyprogesterone & 1.74 & up \\
\hline 47 & MW0132792 & $\mathrm{C}_{15} \mathrm{H}_{10} \mathrm{O}_{5}$ & $3,7,4^{\prime}$-Trihydroxyflavone & -13.61 & down \\
\hline 48 & MW0158708 & $\mathrm{C}_{29} \mathrm{H}_{26} \mathrm{~N}_{2} \mathrm{O}_{7}$ & TyrMe-Nap-OH & 1.70 & up \\
\hline 49 & MW0144201 & $\mathrm{C}_{13} \mathrm{H}_{15} \mathrm{~N}_{3} \mathrm{O}_{7}$ & Abu-Asn-OH & 1.65 & up \\
\hline 50 & MW0139399 & $\mathrm{C}_{16} \mathrm{H}_{12} \mathrm{O}_{6}$ & Pratensein & 1.56 & up \\
\hline 51 & MW0142458 & $\mathrm{C}_{17} \mathrm{H}_{34} \mathrm{O}_{3}$ & $\begin{array}{l}\text { 2-Methoxyhexadecanoic acid } \\
\text { 2-Methoxyhexadecanoate }\end{array}$ & 1.56 & up \\
\hline 52 & MW0123384 & $\mathrm{C}_{24} \mathrm{H}_{34} \mathrm{O}_{7}$ & Clerodin & 1.53 & up \\
\hline 53 & MW0155978 & $\mathrm{C}_{16} \mathrm{H}_{27} \mathrm{~N}_{3} \mathrm{O}_{4}$ & Pro Pro Ile & 1.47 & up \\
\hline 54 & MW0157221 & $\mathrm{C}_{30} \mathrm{H}_{42} \mathrm{O}_{7}$ & Stigmatellin A; Stigmatellin & 1.43 & up \\
\hline 55 & MW0144075 & $\mathrm{C}_{22} \mathrm{H}_{39} \mathrm{NO}_{5}$ & $\begin{array}{l}\text { 8-iso Prostaglandin F2 } \\
\text { Ethanolamide }\end{array}$ & -8.13 & down \\
\hline 56 & MW0137461 & $\mathrm{C}_{20} \mathrm{H}_{22} \mathrm{O}_{3}$ & Avobenzone & 1.37 & up \\
\hline 57 & MW0015339 & $\mathrm{C}_{20} \mathrm{H}_{34} \mathrm{O}_{5}$ & 8-iso-13,14-dihydro-15-keto-PGF2a & 1.36 & up \\
\hline 58 & MW0145074 & $\mathrm{C}_{25} \mathrm{H}_{29} \mathrm{NO}_{4}$ & Ancistrocladine & -11.81 & down \\
\hline 59 & MW0016257 & $\mathrm{C}_{22} \mathrm{H}_{40} \mathrm{O}_{2}$ & Butyl 9,12-octadecadienoate & 1.30 & up \\
\hline 60 & MW0149681 & $\mathrm{C}_{22} \mathrm{H}_{40} \mathrm{~N}_{8} \mathrm{O}_{8}$ & Gln Glu Ile Arg & -1.48 & down \\
\hline 61 & MW0015555 & $\mathrm{C}_{17} \mathrm{H}_{24} \mathrm{O}_{4}$ & Acetylvalerenolic acid & 1.29 & up \\
\hline 62 & MW0116826 & $\mathrm{C}_{21} \mathrm{H}_{28} \mathrm{O}_{4}$ & $\begin{array}{l}\text { 11-nor-9-carboxy-Delta }(9)- \\
\text { tetrahydrocannabinol }\end{array}$ & 1.29 & up \\
\hline 63 & MW0005044 & $\mathrm{C}_{13} \mathrm{H}_{16} \mathrm{O}_{4}$ & $\begin{array}{l}\text { 4-hydroxy-2-methoxy-3-(3-methylbut-2-en-1- } \\
\text { yl)benzoic acid }\end{array}$ & 1.28 & up \\
\hline 64 & MEDP1685 & $\mathrm{C}_{18} \mathrm{H}_{39} \mathrm{NO}_{3}$ & Phytosphingosine & 1.27 & up \\
\hline 65 & MW0012516 & $\mathrm{C}_{22} \mathrm{H}_{36} \mathrm{O}_{6}$ & $\begin{array}{l}\text { 16,16-Dimethyl-6-ketoprostaglandin E1 } \\
5^{\prime} \text {-S-Methyl-5'-thioinosine; }\end{array}$ & 1.22 & up \\
\hline 66 & MW0143701 & $\mathrm{C}_{11} \mathrm{H}_{14} \mathrm{~N}_{4} \mathrm{O}_{4} \mathrm{~S}$ & $\begin{array}{l}5^{\prime}-\text { Deoxy-5'-methylthioinosine; } \\
\text { S-Methyl- } 5^{\prime} \text {-thioinosine }\end{array}$ & 1.20 & up \\
\hline 67 & MEDN1516 & $\mathrm{C}_{15} \mathrm{H}_{10} \mathrm{O}_{3}$ & 6-Hydroxyflavone (6-HF) & 1.16 & up \\
\hline 68 & MW0013392 & $\mathrm{C}_{16} \mathrm{H}_{33} \mathrm{NO}_{2}$ & 2-aminohexadecanoic acid & 1.12 & up \\
\hline 69 & MW0143692 & $\mathrm{C}_{10} \mathrm{H}_{10} \mathrm{~N}_{4} \mathrm{O}_{5}$ & $5^{\prime}$-Oxoinosine; $5^{\prime}$-Dehydroinosine & 1.10 & up \\
\hline 70 & MEDP1360 & $\mathrm{C}_{10} \mathrm{H}_{15} \mathrm{NO}_{6}$ & Mycosporine glycine & 1.01 & up \\
\hline
\end{tabular}




\subsection{Effects of HBA on Bacterial Enzymatic Activity}

Malate dehydrogenase is a key enzyme in bacterial respiration. Figure 7A shows that HBA could inhibit malate dehydrogenase activity. HBA concentration was negatively correlated with malate dehydrogenase activity. When the HBA concentration was $250 \mu \mathrm{g} / \mathrm{mL}$, malate dehydrogenase activity was the lowest at $0.33 \mathrm{U} / \mathrm{mg}$ Prot, which was 0.19 -fold that of the control $(p<0.05)$. This shows that HBA could inhibit bacterial respiration, resulting in decreased energy and weak metabolism, thereby inhibiting bacterial growth.
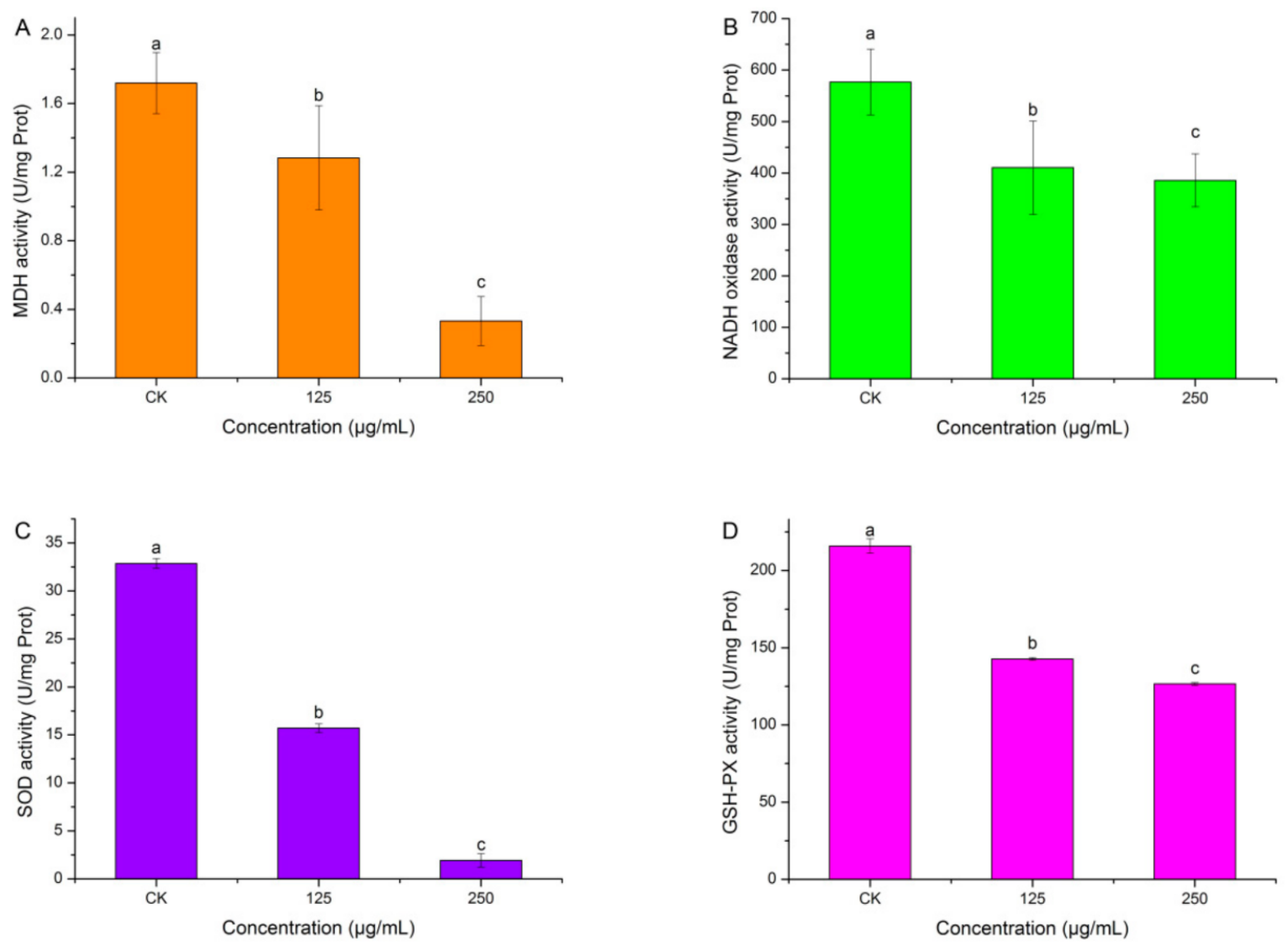

Figure 7. Effect of HBA against respiratory enzymes and antioxidant enzymes activity. Note: (A): MDA: malate dehydrogenase; (B): NADH: NADH oxidase; (C): SOD: total superoxide dismutase; (D): GSH-PX: glutathione peroxidase. Columns followed by different letters indicate significantly different scores in the same phase according to Duncan's multiple range tests at the $p<0.05$ significance level.

NADH oxidase is an important enzyme in bacterial respiration and is also an important antioxidant enzyme. Figure 7B shows that HBA could inhibit NADH oxidase activity. HBA concentration was negatively correlated with NADH oxidase activity. When the HBA concentration was $250 \mu \mathrm{g} / \mathrm{mL}, \mathrm{NADH}$ oxidase activity was the lowest at $385.83 \mathrm{U} / \mathrm{mg}$ Prot, which was 0.67 -fold that of the control $(p<0.05)$. This shows that HBA could inhibit bacterial respiration, resulting in decreased energy and weak metabolism, thereby inhibiting bacterial growth.

SOD is an active substance in organisms that can eliminate harmful substances produced during metabolism. Figure 7C shows that HBA could inhibit SOD activity. The HBA concentration was negatively correlated with SOD activity. When the HBA concentration was $250 \mu \mathrm{g} / \mathrm{mL}$, the SOD activity was the lowest at $1.94 \mathrm{U} / \mathrm{mg}$ Prot, which was 0.06 -fold that of the control $(p<0.05)$. This shows that HBA could disrupt antioxidant capacity in the bacteria, accelerate oxidation, and generate more harmful substances, thereby inhibiting bacterial growth. 
GSH-PX is a scavenging enzyme that can scavenge in vivo hydrogen peroxide to protect cells from $\mathrm{H}_{2} \mathrm{O}_{2}$ toxicity and is an important enzyme in the defense system of an organism. Figure 7D shows that HBA inhibited GSH-PX activity. The HBA concentration was negatively correlated with GSH-PX activity. When the HBA concentration was $250 \mu \mathrm{g} / \mathrm{mL}$, the GSH-PX activity was the lowest at $126.60 \mathrm{U} / \mathrm{mg}$ Prot, which was 0.59 -fold that of the control $(p<0.05)$. This shows that HBA increases hydrogen peroxide and apoptosis.

\subsection{Effects of HBA on Bacterial Cell Membrane Permeability}

Leakage of intracellular small molecules (such as $\mathrm{Na}+$ and $\mathrm{K}+$ ) will occur due to changes in membrane permeability in bacteria, thereby affecting conductivity. Conductivity in the HBA treatment group and control group increased with time, but conductivity in the HBA group was higher than in the control group (Figure 8). The higher the HBA concentration, the higher the conductivity. Conductivity was the highest when the HBA concentration was $250 \mu \mathrm{g} / \mathrm{mL}$. However, conductivity in the low-concentration treatment group was slightly lower than the control at 8 and $24 \mathrm{~h}$, which may be due to new chemical reactions of the leaked ions, resulting in decreased conductivity. In summary, HBA could increase bacterial cell membrane permeability and the leakage of intracellular substances, causing cell death.

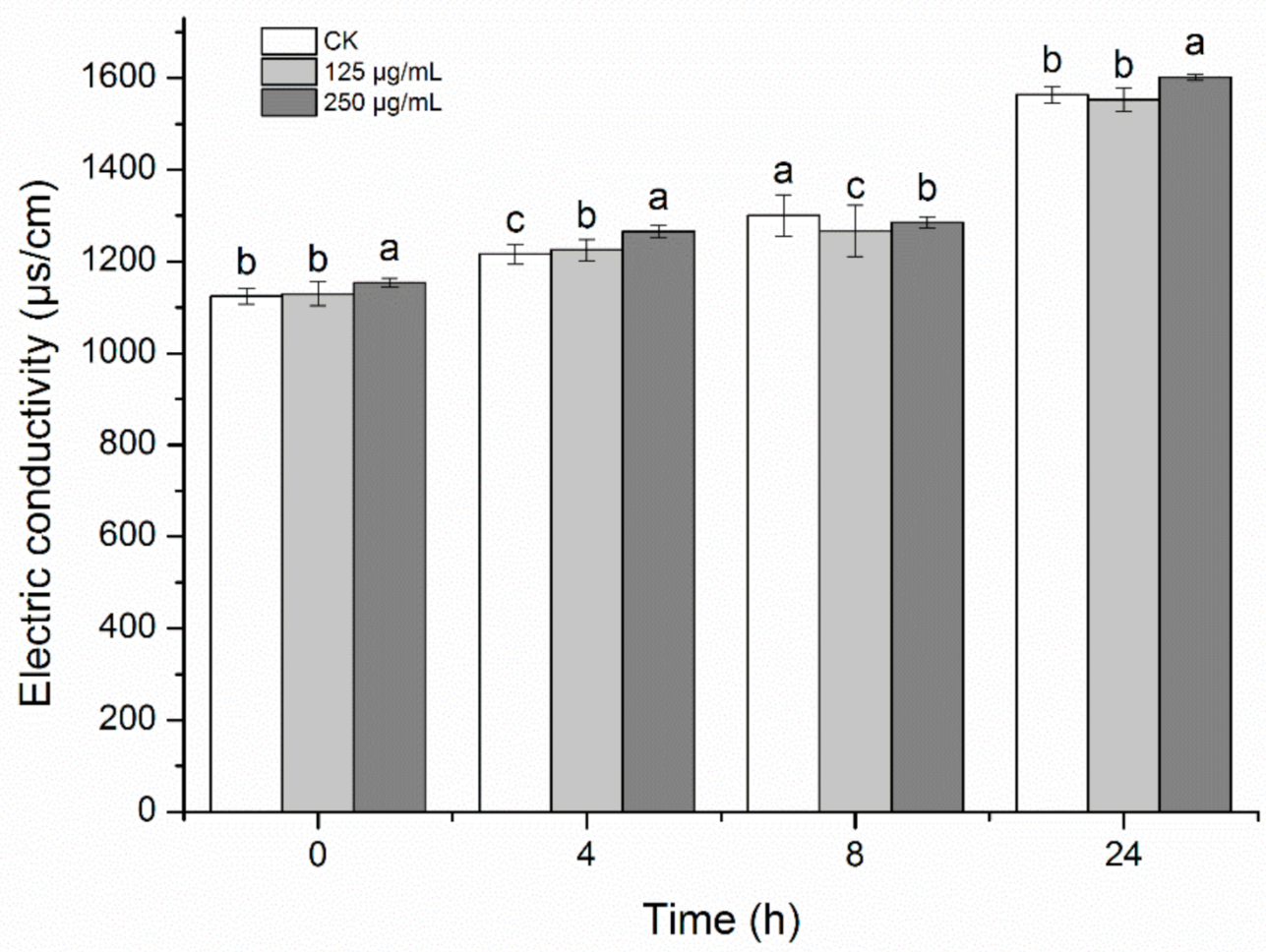

Figure 8. Effect of HBA on membrane permeability of A. avenae subsp. citrulli. Note: Columns followed by different letters indicate significantly different scores in the same phase according to Duncan's multiple range tests at the $p<0.05$ significance level.

\subsection{Effects of HBA on Bacterial Cell Membrane Integrity}

The fluorescent die propidium iodide (PI) is a dye that stains DNA. If PI can permeate the cell membrane and bind to DNA, the cell membrane integrity has been disrupted. If not, cell membrane integrity has not been affected. HBA could affect cell membrane integrity. PI staining was not red in the untreated bacteria (Figure 9A), but it was red in the HBA-treated bacteria (Figure 9B). The HBA concentration was positively correlated with PI staining intensity: the higher the concentration, the better the PI staining result. PI staining was not red in the untreated bacteria (Figure 9C). This shows that HBA could disrupt cell membrane integrity. 

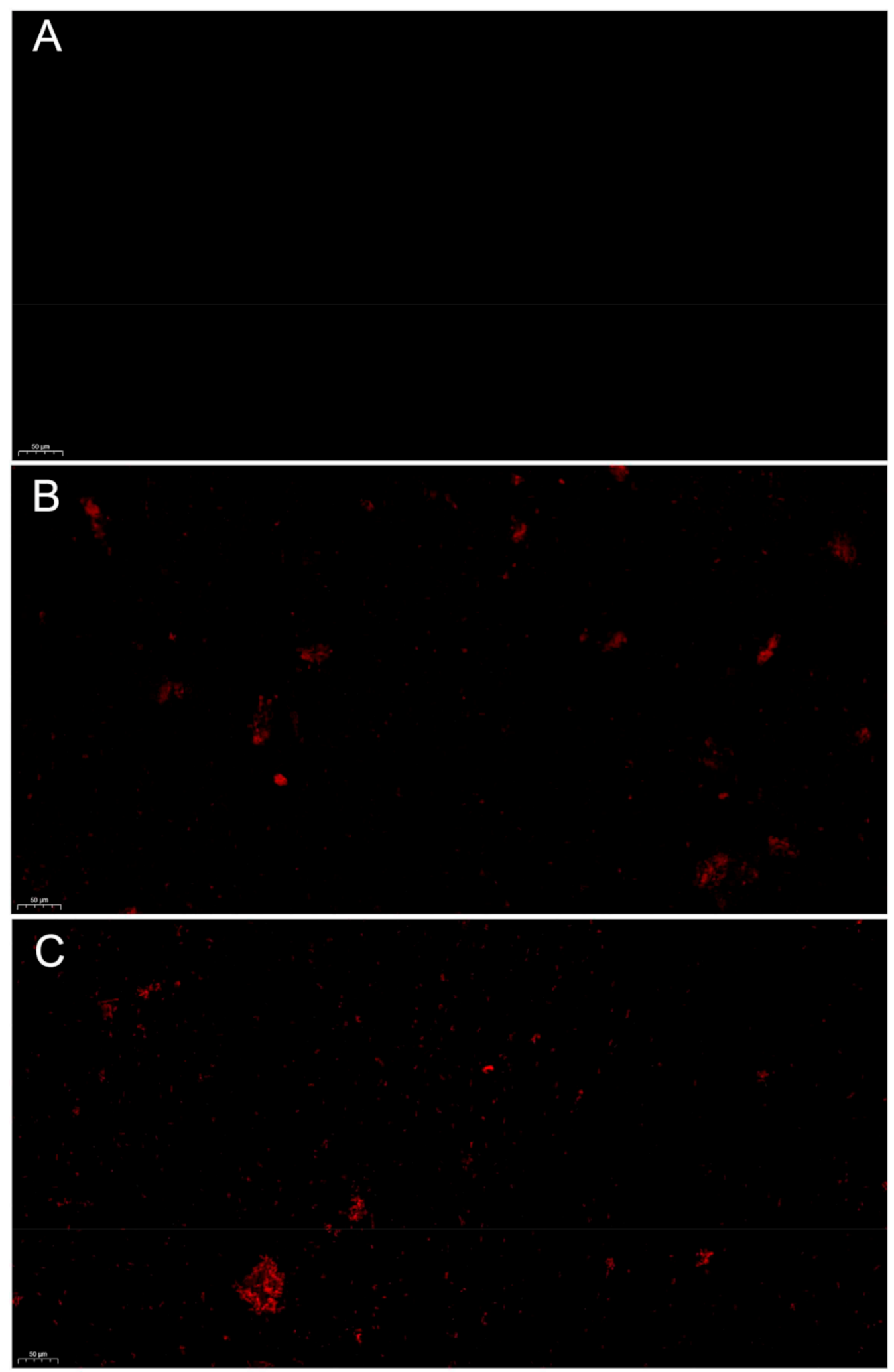

Figure 9. Cell membrane integrity of HBA against $A$. avenae subsp. citrulli. Note: (A): CK; (B): $125 \mu \mathrm{g} / \mathrm{mL} ;(\mathbf{C}): 250 \mu \mathrm{g} / \mathrm{mL}$.

\subsection{HBA on Pyruvate Level in A. avenae subsp. citrulli}

Pyruvate is an important intermediate in the tricarboxylic acid cycle and its level can effectively reflect changes in in vivo metabolic pathways. HBA significantly affected 
the normal metabolism of pyruvate in bacteria. The pyruvate level in the bacteria was significantly higher after HBA treatment compared with the control, and this difference was significant $(p<0.05)$. The higher the HBA concentration, the greater the pyruvate level in the bacteria (Figure 10). This shows that HBA affects the tricarboxylic acid cycle in bacteria and accelerates pyruvate metabolism.

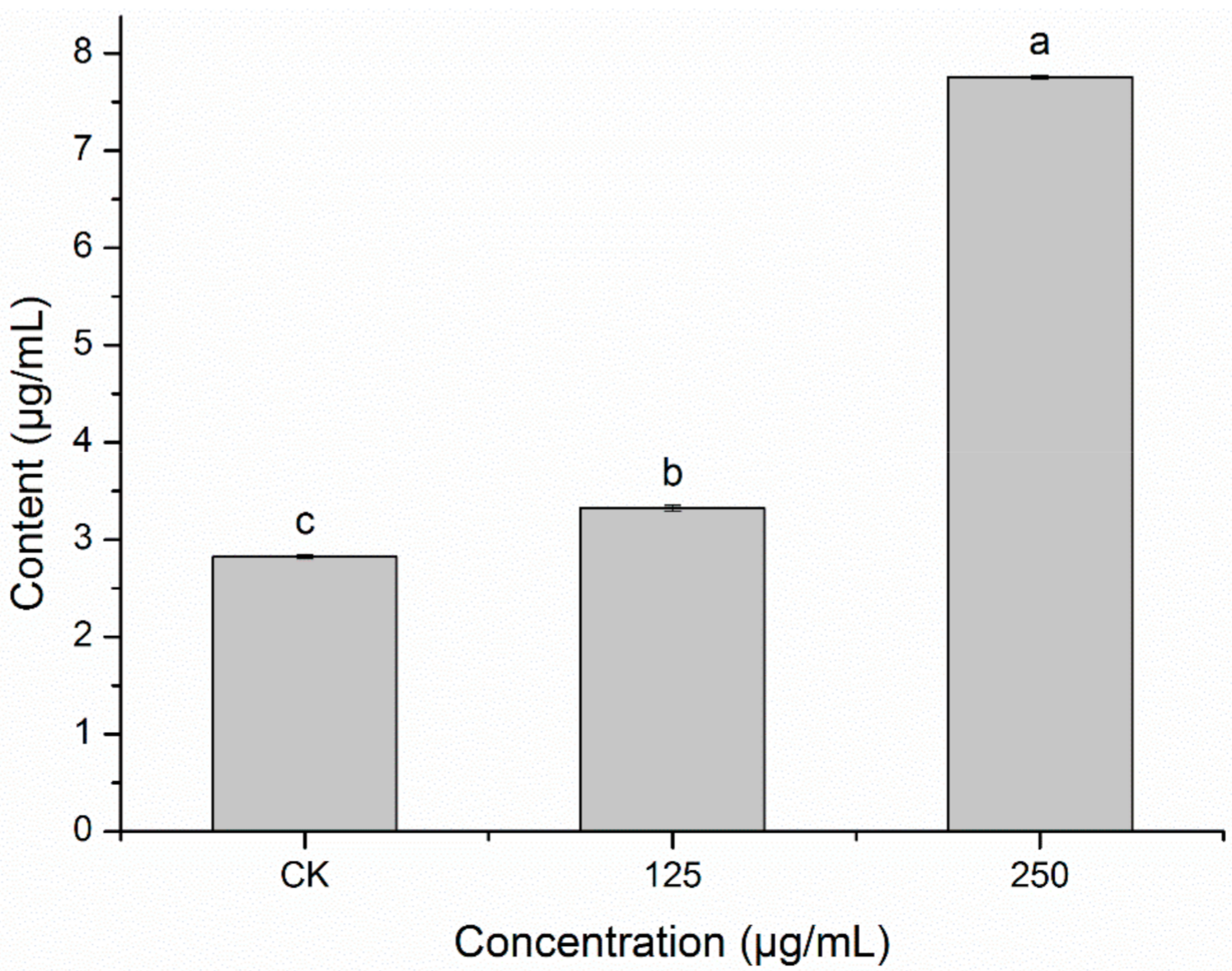

Figure 10. Pyruvic acid content effect of HBA against A. avenae subsp. citrulli. Note: Columns followed by different letters indicate significantly different scores in the same phase according to Duncan's multiple range tests at the $p<0.05$ significance level.

\subsection{Binding Model of HBA and Targets}

SWISS-MODEL was used for model construction. The results showed that MDH, NADH oxidase, SOD, and GSH-PX had the best homology with 1 mld, 5 jwa, 1 ptz, and 6 rjn, respectively, with values of $52.58 \%, 31.22 \%, 55.33 \%$, and $54.57 \%$, respectively. The GMQE was 0.69 and QMEAN was -0.77 for the MDH model; the GMQE was 0.33 and QMEAN was -3.85 for the NADH oxidase model; the GMQE was 0.14 and QMEAN was -0.97 for the SOD model; and the GMQE was 0.59 and QMEAN was -2.80 for the GSH-PX model, showing that these four models were generally reasonable. Verify-3D rationality mainly measures whether the compatibility of the number of amino acids and 3D-1D is $\geq 0.2$. The $\mathrm{MDH}, \mathrm{NADH}$ oxidase, SOD, GSH-PX target model Verify-3D evaluation results were $95.70 \%, 87.73 \%, 99.04 \%$, and $72.96 \%$, respectively, showing that the $\mathrm{MDH}$, NADH oxidase, SOD, and GSH-PX target models were generally reasonable and basically satisfied subsequent molecular docking studies.

Molecular docking was used to study the HBA binding to the MDH, NADH oxidase, SOD, and GSH-PX target models. The results showed that HBA could bind to the MDH, NADH oxidase, SOD, and GSH-PX target models, and the binding free energy was -4.54 , $-4.11,-5.09,-3.73$, respectively, of which HBA showed the best binding result with SOD (Figure 11). 

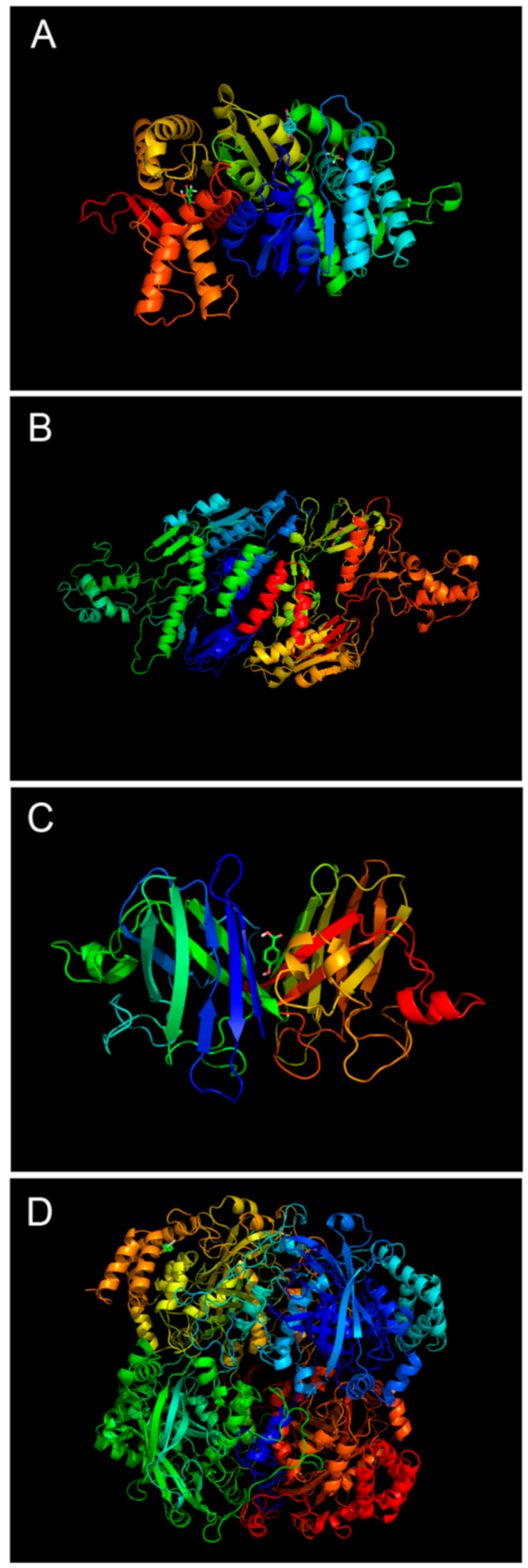

Figure 11. The theoretical binding mode between HBA and target enzymes and the result were shown by PyMoL 1.7.6. Notes: (A): binding complex of HBA and MDH; (B): binding complex of HBA and NADH oxidase; (C): binding complex of HBA and SOD; (D): binding complex of HBA and GSH-PX. 
HBA formed hydrogen bonds with Lys107 and Arg37 in MDH; Arg287 and Ile296 in NADH oxidase; Lys589 in SOD; and Arg620 in GSH-PX. In addition, van der Waals forces, electrostatic interactions, and hydrophobic interactions may be present between HBA and amino acid residues in other target models.

In short, the molecular mechanism of HBA inhibiting A. avenae subsp. citrulli may be as follows: HBA damaged the permeability and integrity of cell membrane, entered the cytoplasm to affect the TCA cycle, destroyed MDH activity, blocked the dehydrogenation of related enzymes, reduced the number of NADH, reduced the activity of NADH oxidase due to the lack of substrate, and abnormal electron transfer in the respiratory chain, which further reduced the activities of SOD and GSH-PX in the antioxidant system, and led to cell apoptosis (Figure 12).
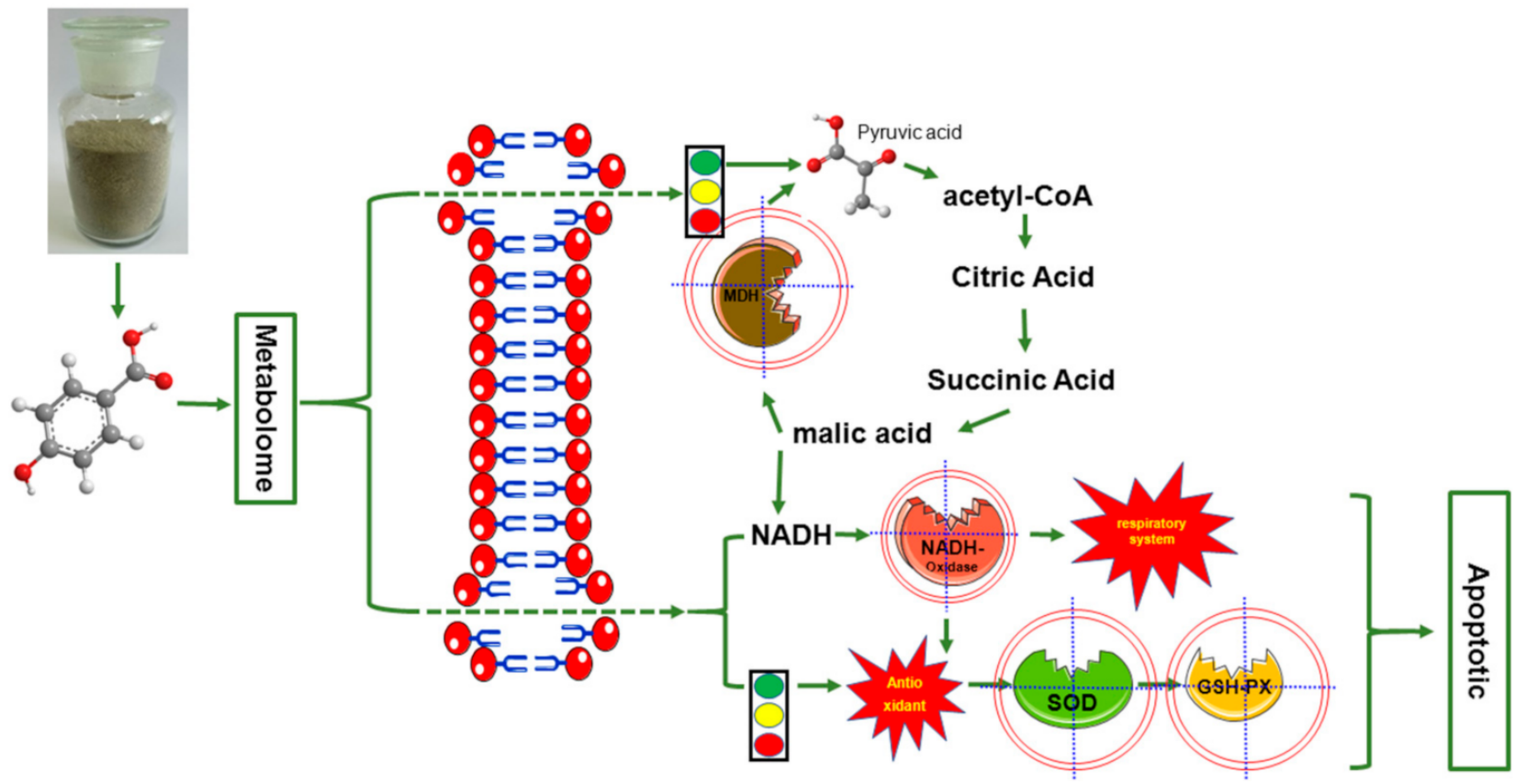

Figure 12. Inhibition molecular mechanism model of HBA against A. avenae subsp. citrulli.

\section{Discussion}

The diversity of plants in nature provides an important material basis for biological pesticide research. Identifying lead compounds with bactericidal effects in plant materials is an integral component of biological pesticide development [23]. Our group previously found that $A$. tricolor is an important precursor material for producing biological pesticide, but its bacteriostatic components and mechanisms were unclear. In this study, we employed column chromatography, TLC, mass spectrometry, and NMR to isolate and identify two active ingredients in $A$. tricolor that inhibit $A$. avenae subsp. citrulli, of which HBA had the best bacteriostatic effects, with a zone of inhibition of $2.29 \mathrm{~cm}$ and MIC of $125 \mu \mathrm{g} / \mathrm{mL}$. $\mathrm{BPC}$ was first isolated from $A$. tricolor but exhibited weak bacteriostatic activity. This is the first study to prove that HBA can inhibit $A$. avenae subsp. citrulli. Studies have found that HBA has applications as a food preservative, pro-apoptosis agent, and liquid crystal material [24-26]. This study identified new functions for HBA. Through a comparison with the toxicity of a commercially available bactericidal compound, we found that the bactericidal effect of HBA was lower than in Zhu et al. but significantly higher than that reported by Chen et al. and Jonkers et al. [27-29]. This shows that HBS is the best candidate compound for the prevention and treatment of $A$. avenae subsp. citrulli. Based on the aforementioned results, SEM was used to examine the effects of HBA on bacterial ultrastructure. The results showed that HBA resulted in bacterial distortion and deformation, uneven surfaces, and even disintegration. This is generally consistent with many previous 
studies [30]. Some lead compounds affect bacterial morphology by inducing shriveling, rupture, fragmentation, disintegration, and deformation, which inhibit bacterial growth and achieve bacteriostatic effects. This shows that HBA has application as a potential bactericidal agent.

Metabolomics was used to study the effects of HBA on metabolites in bacteria. The results showed that there were significant changes in bacterial metabolites after HBA treatment, indicating that HBA can result in metabolic disturbance in bacteria. The study of Tremaroli et al. proved that metals can result in metabolic changes in bacteria [31]. This shows that compounds can cause metabolite changes in bacteria, which is an important pathway for discovering new effector targets [32]. HBA mainly affected metabolites such as strigolactones, organic acids, fatty acids, benzene and substituted benzene derivatives, amino acids, alcohols, amines, and other metabolites. These metabolites play important roles in life activities in cells.

Amino acids are the precursors of proteins and nucleotides and participate in in vivo protein and nucleotide synthesis $[33,34]$. The results of this study showed that significant changes occurred in many amino acids, of which the downregulation of S-adenosyl-Lmethionine (MEDP1280) was the most critical, as it affected the biosynthesis of amino acids, monobactam biosynthesis, arginine and proline metabolism, and the sulfur relay system. The results of previous studies proved that S-adenosyl-L-methionine has methyltransferase, sulfotransferase, and aminopropyl transferase effects and is a precursor for cysteine, taurine, glutathione, and coenzyme A [35]. The results of this study were generally consistent with the amino acid results of previous studies, proving that amino acids are an important bactericidal target and suggesting that amino acids may be HBA targets [36]. However, whether the reason for the downregulation of these substances was due to decreased synthase activity or the consumption of downstream metabolites remains to be determined. Of course, downregulation of these substances can stop the downstream synthesis of cysteine and glutathione, thereby causing bacterial death. This shows that these substances may be potential targets of HBA.

Organic acids in bacteria can maintain a neutral $\mathrm{pH}$ to ensure that enzymes can work normally [37]. The results of this study showed that 2,5-dihydroxy benzoic acid (MEDN0089) was upregulated several-fold higher than 2-amino-3-phosphonopropionic acid (MW0104504), which may cause organic acid levels to increase more than decrease, showing that elevated intracellular $\mathrm{pH}$ can be used to resist HBA stress. However, $\mathrm{pH}$ elevation causes dysregulated enzyme function and accelerated cell senescence. Second, the subsequent enzymatic activity measurements in this study also confirmed this point. Antioxidant enzyme activity decreased after HBA treatment, particularly GSH-PX. This directly resulted in intracellular reactive oxygen species accumulation. Excess reactive oxygen species will attach unsaturated fatty acids to the cell membrane, resulting in cell disruption, protein disturbances, and the production of aldehydes, further damaging cells. Messenger metabolites also play important intracellular roles. The results of this study showed that HBA can downregulate Bis(1-inositol)-3,1'-phosphate 1-phosphate (MEDN1224), which usually acts as a messenger and has important regulatory effects in cells. This suggests that HBA could block signaling molecule activity and intracellular signal transduction to impede bacterial growth, and these may be the potential targets of HBA. In addition, intracellular phenolic metabolites are mostly related to stress resistance. The results of this study showed that phenol (MEDL01916) and 2-(4-hydroxyphenyl) ethanol (MEDN0554) were upregulated, suggesting that these may be related to stress resistance. Fatty acids can provide energy, and saturated fatty acids mostly accelerate apoptosis, while unsaturated fatty acids do not have this function [38]. The results of this study showed that intracellular palmitoleic acid (MEDN0380) and tetracosanoic acid (MW0169908) were upregulated after HBA treatment. This was opposite to the results of Wang et al., who found that intracellular fatty acids were downregulated when bacteria were stimulated in a space environment [39]. This shows that changes in fatty acid metabolism differ under different external conditions. The reason for this may be that the effects of different external stimuli on signaling 
substances vary, thereby affecting signal transduction and resulting in differences in fatty acid metabolism.

The cell membrane can maintain cell morphology and has protective effects on the cell. At the same time, the cell membrane must take in essential nutrients and oxygen from the surrounding environment and expel metabolites. The cell membrane has selective permeability and can exclude harmful substances or macromolecules from entering the cell to maintain intracellular homeostasis.

Therefore, cell membrane integrity affects the life activities of the cell. The results of this study showed that HBA can damage cell membrane permeability and result in the leakage of intracellular substances. The PI staining results also showed that HBA could disrupt cell membrane integrity. This indicates that the cell membrane may be a potential effector target of HBA. This is generally consistent with previous reports that bactericidal compounds act on the cell membrane and confirms that HBA has basic bactericidal characteristics and can be used to develop a bactericide [40]. However, how HBA disrupts cell membrane permeability and integrity, such as what substances are first bound by HBA, what responses are triggered after binding, and what effects occur after these responses, requires further analysis.

Respiration is an important means for organisms to perform life activities and is characterized by intracellular oxidative metabolism. The inhibition of glucose metabolism will block organism growth and proliferation and may even lead to death [41]. The results of this study showed that HBA can increase the pyruvate level in bacteria, indicating that the TCA cycle is disrupted after HBA treatment. To resist this disruption, pyruvate levels increase to compensate for energy deficiency. However, further studies are required to understand when pyruvate levels start to increase, peak, and end, and what the subsequent cascade effects after HBA treatment are. Second, HBA can also decrease the activities of MDH and NADH oxidase, proving that HBA inhibits bacterial respiration to decrease energy and slow down metabolism. However, further studies are required to determine if HBA influences other respiratory enzymes, whether inhibition is simultaneous or successive, and what factors control these enzymes.

Antioxidant enzymes are biological catalysts produced in vivo that can slow down oxidation speed. Antioxidant enzymes is an umbrella term for SOD, catalase, etc. Once peroxides are produced, these enzymes immediately perform their functions and use oxidoreduction to convert peroxides to harmless or less toxic substances [42]. Studies have found that HBA decreases SOD and GSH-PX activities, suggesting that HBA acts on the antioxidant enzyme system. An impaired antioxidant system in bacteria causes them to be susceptible to death.

Molecular docking was used to study the binding between HBA and respiratory and antioxidant enzymes. The results showed that HBA could bind to MDH, NADH oxidase, SOD, and GSH-PX, of which SOD exhibited the best binding, showing that SOD may be an effector target of HBA. However, binding between HBA and these enzymes was not optimal, and molecular dynamics should be used in future studies to determine optimal binding methods.

Amaranthus tricolor has diverse and complex components. In this study, column chromatography was used for isolation and purification, and most of the substances obtained were acidic substances. However, previous studies reported that other types of bacteriostatic compounds are present in A. tricolor. Therefore, the isolation and purification methods could be further improved to obtain more valuable natural active compounds. Second, this study only performed indoor toxicity evaluation. In the future, field prevention and treatment studies could be considered to further validate the bacteriostatic activity of HBA, which will help guide subsequent studies. Third, in-depth studies are required to determine if HBA will affect the pathogenic secretory systems (type II and III) in the bacteria, exopolysaccharide (EPS), toxins, growth regulators, and flagella [43-46]. Lastly, future studies are required to determine if HBA has regulatory effects on the cell wall, nucleic acid, and protein synthesis and whether there are new effector targets. 


\section{Materials and Methods}

\subsection{Test Plants}

The A. tricolor plants were cultivated at the Liuyang Research Base of Hunan Agricultural University for 2 months. Mature A. tricolor plants $(16-24 \mathrm{~cm}$ in height) were harvested and their leaves were collected, washed, and dried until the leaf moisture content was controlled at $<5 \%$. An XY-200 leaf pulverizer (Zhejiang Yongkang Songqing Hardware Factory) was used to powder the leaves, which was referred to as A. tricolor powder (A). The powder was stored dry at room temperature.

\subsection{Preparation of Culture Media}

Beef extract peptone culture medium (NA) consisting of $5.0 \mathrm{~g}$ beef extract, $10.0 \mathrm{~g}$ peptone, $5.0 \mathrm{~g} \mathrm{NaCl}, 40.0 \mathrm{~g}$ agar, and $1000 \mathrm{~mL}$ distilled water at $\mathrm{pH} 7.0-7.2$ was used. The above materials were heated and dissolved in $1000 \mathrm{~mL}$ distilled water. Water loss was topped up. After the substances had completely dissolved, agar was added and stirred until complete dissolution. The $\mathrm{pH}$ was adjusted to 7.0-7.2. The medium was aliquoted into $250 \mathrm{~mL}$-conical flasks and autoclaved at $121^{\circ} \mathrm{C}$ for $20 \mathrm{~min}$ before cooling [47].

\subsection{Bacterial Strain Activation}

The $A$. avenae subsp. citrulli was removed from the freezer and thawed to room temperature. An inoculating loop was used to select bacteria for inoculation onto fresh NA culture medium. This step was repeated 2-3 times. The bacteria were cultured continuously for 2-3 generations at $28-30^{\circ} \mathrm{C}$, and bacteria with good activity were selected.

\subsection{Preparation of A. tricolor Ester Extract}

Five volumes of ethyl acetate were used to extract $6.5 \mathrm{~kg}$ of $A$. tricolor powder (A) for $6 \mathrm{~h}$ with shaking (rotation speed: $150 \mathrm{r} / \mathrm{min}$, temperature: $26 \pm 1^{\circ} \mathrm{C}$ ). After leaving to stand for $24 \mathrm{~h}$, the extract was filtered, and the same volume of ethyl acetate was used for crude extraction of the residue for $24 \mathrm{~h}$ before filtration. The filtrates were combined and subjected to rotary concentration at $40{ }^{\circ} \mathrm{C}$ to obtain a paste. The paste was weighed, named $A$. tricolor black crude extract (B), and stored at $4{ }^{\circ} \mathrm{C}$. The above filtrates were also eluted by carbon column chromatography to remove the pigment in the crude extract. The chromatography column was filled with the activated carbon powder and diatomite at a 2:1 ratio, and the eluant was ethyl acetate. The colorless chromatography liquid was finally rotary concentrated at $40{ }^{\circ} \mathrm{C}$ to obtain a colorless paste, named $A$. tricolor colorless extract and stored at $4{ }^{\circ} \mathrm{C}$.

\subsection{Measurement of A. tricolor Ester Extract Activity}

Activated $A$. avenae subsp. citrulli was diluted with sterile water to prepare a $1 \times 10^{8} \mathrm{cfu} / \mathrm{mL}$ bacterial suspension. Three milliliters of suspension and $27 \mathrm{~mL}$ of NA culture medium were fully mixed and poured onto a sterile Petri dish. After the culture medium had completely solidified, a hole punch was used to punch wells, and $200 \mu \mathrm{L}$ of A. tricolor black crude extract (B) was added to the wells. An untreated plate was used as a control. Each treatment was repeated in triplicate. The Petri dishes were cultured at $28-30^{\circ} \mathrm{C}$. After bacterial growth in the blank control plate was confluent, the zone of inhibition was measured. In addition, the minimum inhibitory concentration (MIC) was measured as described previously [48]: The final concentration of novel fungicide HBA, BFC and ZSM were 0.5 times gradient decrement from left to right using the double dilution method of a 96-well plate with each treatment in duplicate. The first well contained $500.00 \mu \mathrm{g} / \mathrm{mL}$ and the second well contained $250.00 \mu \mathrm{g} / \mathrm{mL}$, etc. The ZSM was used as a positive control, and the untreated wells were used as a negative control. The Petri dishes were cultured at $28-30{ }^{\circ} \mathrm{C}$ for $24 \mathrm{~h}$, and the lowest concentration with no bacterial growth was considered to be the MIC for $A$. tricolor pure product. 


\subsection{Silica Gel Column Chromatography}

The A. tricolor black crude extract (B) was dissolved in $500 \mathrm{~mL}$ ethyl acetate, and the solution was slowly injected into an activated carbon column so that the crude extract slowly passed through the carbon powder column to remove pigments in the extract. The column was repeatedly washed with ethyl acetate until the eluate was colorless. All of the filtrates were collected and subjected to rotary evaporation at $40{ }^{\circ} \mathrm{C}$ until a paste was obtained, which was named A. tricolor yellow paste (C). A silica gel column (glass column diameter and height of $6.5 \times 60 \mathrm{~cm}$, column volume: $200 \mathrm{~mL}$ ) was used for isolation. The sample was loaded using the wet method. Thirty-four grams of $A$. tricolor yellow paste (C) was loaded, and gradient elution was carried out using trichloromethane:methanol = 1:0, 9:1, 4:1, 7:3, 3:2, 0:1 (V/V). Collection was performed once every $250 \mathrm{~mL}$, and TLC was used to test every fraction. Fractions with the same components were combined and subjected to vacuum concentration before the bacteriostatic activity was measured. The bacteriostatic fractions were named as $A$. tricolor bacteriostatic fraction (D) and stored at $-20^{\circ} \mathrm{C}$.

\subsection{ODS-C18 Reverse-Phase Chromatography}

The dry method was used to pack ODS-C18 filler into the column. The filler occupied $98 \%$ of the column, and methanol was used to wet the column. A medium pressure constant current pump was used to slowly add methanol into the reverse-phase column, and the flow rate was controlled at $2.22 \mathrm{~mL} / \mathrm{min}$. After no bubbles appeared and the filler had been completely immersed in methanol, the flow rate was increased to $4.44 \mathrm{~mL} / \mathrm{min}$ and washing was continued for $2 \mathrm{~h}$. Methanol (30\%) was used to wash the column for $6 \mathrm{~h}$ at $2.22 \mathrm{~mL} / \mathrm{min}$. Then, 3-5 g of A. tricolor bacteriostatic fraction (D) was mixed evenly with an appropriate amount of ODS-C18 silica gel. The solvent was completely evaporated for loading. The silica gel was added to the reverse-phase column and the elution sequence was performed: $30-100 \%$ methanol for gradient elution at a flow rate of $4.44 \mathrm{~mL} / \mathrm{min}$. Every elution was washed with $1000 \mathrm{~mL}$ of elution solution and collection was performed every $100 \mathrm{~mL}$. TLC was used to test every fraction. Fractions with the same components were combined and subjected to vacuum concentration before the bacteriostatic activity was measured. Fractions with bacteriostatic activity were named $A$. tricolor bacteriostatic fraction (E) and stored at $-20{ }^{\circ} \mathrm{C}$.

\subsection{Sephadex LH-20 Gel Filtration Chromatography}

Three-hundred grams of Sephadex LH-20 gel was weighed in a beaker, and $500 \mathrm{~mL}$ of pure methanol was added to soak the gel overnight. The column was loaded using the wet method. The treated gel was stirred until the solution became turbid. A glass rod was used to place the soaked gel onto a $1.5 \times 200 \mathrm{~cm}$ column. The entire gel was completely transferred to the column, and pure methanol was used for flushing. After continuous flushing for $2 \mathrm{~h}$, the column piston was closed. The solvent level was $10 \mathrm{~cm}$ from the gel. The column was left to stand overnight. The bottom piston was removed to allow liquid from the gel filtration column to flow out. The solvent level in the solid phase was controlled at $0.5 \mathrm{~cm}$ from the gel level and the column piston was closed. The A. tricolor bacteriostatic fraction (E) was dissolved in 1-2 $\mathrm{mL}$ of pure methanol, and a long dropper was used to slowly add the dissolved sample onto the gel filtration column. After the sample was completely transferred to the column, the piston was opened, and the sample solution was allowed to completely immerse in the solid phase at a flow rate of $0.5 \mathrm{~mL} / \mathrm{min}$. After that, methanol was used for elution. Collection was performed every $5 \mathrm{~mL}$. Each tube of eluate underwent TLC analysis, and identical fractions were combined and subjected to vacuum concentration before the bacteriostatic activity was measured. Highly pure compounds 1 and 2 were obtained.

\subsection{Structural Identification of Compounds}

The electrospray ionization-mass spectrometry (ESI-MS) working conditions were as follows: the MS column was $2.6 \mathrm{~mm} \times 250 \mathrm{~mm}, 2 \mu \mathrm{m}$; the detection wavelength was 
$254 \mathrm{~nm}$; the flow rate was $0.5 \mathrm{~mL} / \mathrm{min}$; the electrospray operating voltage was $4.02 \mathrm{kV}$; the operating current was $0.39 \mu \mathrm{A}$; the capillary temperature was $275^{\circ} \mathrm{C}$; and the drying gas $\left(\mathrm{N}_{2}\right)$ flow rate was $19.92 \mathrm{~L} / \mathrm{min}$.

The NMR operating conditions were as follows: the sample was dissolved in deuterated chloroform (CDC13), or deuterated methanol (CD4O) and scanning was performed on a Bruker Avance $500 \mathrm{MHz}$ spectrometer. The hydrogen spectrum and carbon spectrum were obtained, and the test temperature was $297.3 \mathrm{~K}$. Tetramethylsilane (TMS) was used as an internal standard for both the hydrogen and carbon spectra. The test spectrum width of the $1 \mathrm{H} \mathrm{NMR}$ and $13 \mathrm{C}$ NMR spectra was 10,330.578 and 22,058.824 Hz, respectively.

\subsection{Effects of HBA on Bacterial Ultrastructure Using Scanning Electron Microscopy (SEM)}

A small volume of methanol and compound 1 was used to prepare $125 \mu \mathrm{g} / \mathrm{mL}$ bacteriacontaining solution, with a bacteria-free solution used as a control. The solutions were cultured with shaking at $180 \mathrm{r} / \mathrm{min}$ for $24 \mathrm{~h}$. After that, the solutions were centrifuged at $10,000 \mathrm{r} / \mathrm{min}$ for $5 \mathrm{~min}$. The supernatant was discarded, and $2 \mathrm{~g}$ of pellet was collected. After processing with the electron microscopy fixing solution (Reagent number: G1102, Wuhan Servicebio Technology Co., Ltd., Wuhan, China), electron microscopy observation of bacterial changes was performed as described [49].

\subsection{Bacterial Metabolome}

The method in 2.10 was used to process the bacteria, and the processing groups were named TM1, TM2, and TM3 and the control groups were named CK1, CK2, and CK3. Around $2 \mathrm{~g}$ of pellet was collected and frozen in liquid nitrogen. The samples were stored in a $-80^{\circ} \mathrm{C}$ freezer before sending to a biotechnology company for metabolomics testing. For extraction, the samples were removed from the $-80{ }^{\circ} \mathrm{C}$ freezer and thawed on ice. Two-hundred microliters of ultrapure water extraction solution was added, and the samples were vortexed for 3 min until the cell suspension was uniform. When there was difficulty obtaining a uniform suspension, a pipette was used to mix the sample. One-hundred microliters of cell suspension was aspirated into the corresponding centrifuge tube, and $400 \mu \mathrm{L}$ pure methanol internal standard extraction solution was added. Samples were vortexed for $1 \mathrm{~min}$. Centrifuge tubes were snap-frozen in liquid nitrogen for $5 \mathrm{~min}$ and thawed on dry ice for $5 \mathrm{~min}$ before thawing on ice for $5 \mathrm{~min}$. Samples were vortexed for 2 min to mix evenly before snap-freezing, thawing, and vortexing, which were repeated thrice. Samples were centrifuged at $4^{\circ} \mathrm{C}$ and $12,000 \mathrm{r} / \mathrm{min}$ for $10 \mathrm{~min}$. Three-hundred microliters of supernatant was aspirated to the corresponding numbered centrifuge tube and left to stand in a $-20{ }^{\circ} \mathrm{C}$ freezer for $30 \mathrm{~min}$. The tubes were recentrifuged at $4{ }^{\circ} \mathrm{C}$ and 12,000 r/min for $3 \mathrm{~min}$. Two-hundred microliters of supernatant was aspirated to the sampling vial and used for UPLC-MS-MS analysis.

For the liquid chromatography analysis, the data acquisition instrument system mainly included an Ultra-Performance Liquid Chromatograph (UPLC) (ExionLC AD, https: / / sciex. com.cn, accessed on 15 October 2021) and tandem mass spectrometry (MS/MS) (QTRAP ${ }^{\circledR}$, https: / / sciex.com, accessed on 17 October 2021).

The chromatography column was a Waters ACQUITY UPLC HSS T3 C18 $1.8 \mu \mathrm{m}$, $2.1 \mathrm{~mm} \times 100 \mathrm{~mm}$; mobile phase A was ultrapure water $(0.1 \%$ formic acid $)$ and mobile phase $\mathrm{B}$ was acetonitrile ( $0.1 \%$ formic acid); the elution gradient was $0 \mathrm{~min}$ water/acetonitrile (95:5 V/V), $11.0 \mathrm{~min}: 10: 90 \mathrm{~V} / \mathrm{V}, 12.0 \mathrm{~min}: 10: 90 \mathrm{~V} / \mathrm{V}, 12.1 \mathrm{~min}: 95: 5 \mathrm{~V} / \mathrm{V}, 14.0 \mathrm{~min}: 95: 5 \mathrm{~V} / \mathrm{V}$; the flow rate was $0.4 \mathrm{~mL} / \mathrm{min}$; the column temperature was $40{ }^{\circ} \mathrm{C}$; and the sample volume was $2 \mu \mathrm{L}$. The T3 method was used for the generation of mass spectra with an electrospray ionization (ESI) temperature of $500{ }^{\circ} \mathrm{C}$; mass spectrometry voltage of $5500 \mathrm{~V}$ (positive) and $-4500 \mathrm{~V}$ (negative); ion source gas I (GS I) of 55 psi; gas II (GS II) of 60 psi; and curtain gas (CUR) of 25 psi; and the collision-activated dissociation (CAD) parameter was set as high. In the triple quadrupole (Qtrap), every ion pair was scanned and detected based on the optimized declustering potential (DP) and collision energy (CE) [50]. Analyst1.6.3 software was used to process the mass spectrometry data. 


\subsection{Bacterial Cell Membrane Permeability}

Based on the experimental method of Wei [51], the density of the A. avenae subsp. citrulli suspension in the logarithmic growth phase was adjusted to OD600 $=0.5$, and HBA was added to a final concentration of 125 and $250 \mu \mathrm{g} / \mathrm{mL}$. Ultrapure water was used as a control. After treatment for $0,4,8$, and $24 \mathrm{~h}, 5 \mathrm{~mL}$ of culture medium was collected and centrifuged at $6000 \mathrm{r}$ for $10 \mathrm{~min}$. The supernatant was diluted 20-fold with ultrapure water, and a conductivity meter was used to measure conductivity. Every treatment was performed in triplicate.

\subsection{Bacterial Cell Membrane Integrity}

The bacteria were processed according to the method in 4.10, and PI staining was performed according to Chavan and Tupe [52] to observe the effects of compound 1 on bacterial cell membrane integrity.

\subsection{Effects of HBA on Bacterial Pyruvate Level}

The bacteria were processed according to the method in 4.10, and the method of Huang et al. [53] was used to measure the pyruvate level.

\subsection{Effects of HBA on Bacterial Enzymatic Activity}

The logarithmic growth phase bacterial suspension was adjusted to $\mathrm{OD}_{600}=0.5$, and HBA was added to a final concentration of 125 and $250 \mu \mathrm{g} / \mathrm{mL}$. The bacteria-free suspension was used as a control. Samples were cultured for $24 \mathrm{~h}$ at $28-30{ }^{\circ} \mathrm{C}$. Two milliliters of the solution was collected and centrifuged at $4{ }^{\circ} \mathrm{C} 600 \mathrm{rpm}$ for $5 \mathrm{~min}$. The pellet was dissolved in phosphate buffer and sonicated (power: $100 \%$, sonication duration: $3 \mathrm{~s}$, interval: $10 \mathrm{~s}$, repeated 30 times). The solution was centrifuged at $4{ }^{\circ} \mathrm{C}$ and $11,000 \mathrm{rpm}$ for $10 \mathrm{~min}$. The supernatant was then collected, and the concentration of the crude enzyme was measured. Coomassie blue was used to measure the concentration of the crude enzyme. Enzyme activity was measured according to the malate dehydrogenase A021-2-1 (MDH, Nanjing Jiancheng Bioengineering Institute), NADH oxidase A020-1-1 (NADH, Nanjing Jiancheng Bioengineering Institute), superoxide dismutase A001-1 (SOD, Nanjing Jiancheng Bioengineering Institute), and glutathione peroxidase A005-1 (GSH-PX, Nanjing Jiancheng Bioengineering Institute) assay kits. Each treatment was performed three times.

\subsection{Molecular Docking}

The amino acid sequences of MDH A021-2-1 (Nanjing Jiancheng Bioengineering Institute), NADH oxidase A020-1-1 (NADH, Nanjing Jiancheng Bioengineering Institute), superoxide dismutase A001-1 (SOD, Nanjing Jiancheng Bioengineering Institute), and glutathione peroxidase A005-1 (GSH-PX, Nanjing Jiancheng Bioengineering Institute) were obtained from the GenBank database, and Blast was used to search for homology models on the website. The SWISS-MODEL (http:/ / swissmodel.Expasy.org, accessed on 6 August 2021) program was used to construct the molecular model of the target protein. The structure of HBA was plotted using ChemBioDraw Ultra 12.0 (PerkinElmer Co., Ltd., MA, USA) and converted into a three-dimensional structure. At the same time, optimization was performed. GMQE, QMEAN, and Verify-3D were used to evaluate the quality of the protein model. Autodock v4.2 (Olson Laboratory of Scripps Institute, La Jolla, CA, USA) was used for molecular docking, and the results were analyzed using Pymol v1.7.6.

\subsection{Data Analysis}

The ${ }^{1} \mathrm{H}-\mathrm{NMR}$ and ${ }^{13} \mathrm{C}-\mathrm{NMR}$ data were processed using the software (MestReNov v14.0, Mestrelab Research S.L, San Diego, Spain) provided with the instrument. A completely random design was employed for the experiment. Excel v2016 was used for statistical analysis of the data. All of the data represent the mean and standard deviation of triplicates. Origin software was used for graph plotting. Duncan's new multiple range test in DPS v 6.55 was used for significant difference analysis. 


\section{Conclusions}

This study was the first to develop a method for isolating and purifying A.tricolor substances that inhibit $A$. avenae subsp. citrulli viability. Two components were identified, of which HBA had the highest bacteriostatic activity and potential use in the development of a biological pesticide. Further analysis found that HBA could cause bacteria to become shriveled, distorted, and deformed and cause uneven bacterial surfaces. Metabolomics analysis found that 70 differentially expressed metabolites that respond to HBA were detected, of which 9 were downregulated (which may be potential effector targets) and 61 were upregulated (which may be related to drug resistance). The differentially expressed metabolites were mainly strigolactones, organic acids and derivatives, fatty acids, benzene and substituted benzene derivatives, amino acids and associated metabolites, alcohols and amines, and other metabolites. Among all of the downregulated metabolites, S-adenosylL-methionine (MEDP1280) was the most critical as it participates in many physiological and biochemical processes. The KEGG enrichment analysis showed that the differentially expressed metabolites mainly participated in tyrosine metabolism, biosynthesis of amino acids, and cysteine and methionine metabolism. HBA can disrupt cell membrane permeability and integrity. The pyruvate level increased, while the activities of MDA, NADH oxidase, SOD, and GSH-PX decreased after HBA treatment. The inverse molecular docking study results showed that HBA could dock to MDA and NADH oxidase, SOD, and GSH$\mathrm{PH}$, of which the docking result was the best for SOD, suggesting that SOD may be the best effector target of HBA.

Author Contributions: Y.Z. designed and wrote the manuscript. K.G. analyzed the data. C.W. edited the manuscript. S.L. administered the project. All authors have read and agreed to the published version of the manuscript.

Funding: This research was funded by the Nature Science Foundation of Hunan Province, grant number 2019JJ40125; double first-class construction project of Hunan Agricultural University, grant number SYL2019033.

Institutional Review Board Statement: Not applicable.

Informed Consent Statement: Not applicable.

Data Availability Statement: The authors declare that the data supporting this study are available from the corresponding author on reasonable request.

Conflicts of Interest: The authors declare no conflict of interest.

\section{References}

1. Liu, S.C.; Kuang, H.Q.; Lai, Z.X. Transcriptome analysis by illumina high-throughput paired-end sequencing reveals the complexity of differential gene expression during in vitro plantlet growth and flowering in Amaranthus tricolor L. PLoS ONE 2014, 9, e100919.

2. Shao, L.; Chen, T.M. Analysis on the physiological characteristics and cultivation techniques of amaranth in autumn and winter. Plant Physiol. J. 2019, 55, 1355-1364.

3. Sarker, U.; Oba, S. Drought stress effects on growth, ROS markers, compatible solutes, phenolics, flavonoids, and antioxidant activity in Amaranthus tricolor. Appl. Biochem. Biotechnol. 2018, 186, 999-1016. [CrossRef] [PubMed]

4. Sarker, U.; Oba, S. Leaf pigmentation, its profiles and radical scavenging activity in selected Amaranthus tricolor leafy vegetables. Sci. Rep. 2020, 10, 18617. [CrossRef]

5. Sarker, U.; Islam, M.T.; Rabbani, M.G.; Oba, S. Variability in total antioxidant capacity, antioxidant leaf pigments and foliage yield of vegetable amaranth. J. Integr. Agric. 2018, 17, 1145-1153. [CrossRef]

6. Zhao, C.L.; Chen, J.L.; Wang, L.; Chen, H.; Zheng, Y.F.; Xiao, F.; Lai, Z.X.; Liu, S.C. Effects of temperature on the betalian content and expression of related gene in amaranth seedlings. Chin. J. Appl. Environ. Biol. 2020, 26, 1484-1489.

7. Yustiati, A.; Zurwana, S.I.; Rizal, A.; Andriani, Y. Promoting color brightness of clown loach (Chromobotia macracanthus Bleeker) by mixing red spinach (Amaranthus tricolor L.) powder with feed stuff. Asian. J. Fish. Aqua. Res. 2020, 9, 21-30. [CrossRef]

8. Jayaprakasam, B.; Zhang, Y.; Nair, M.G. Tumor cell proliferation and cyclooxygenase enzyme inhibitory compounds in Amaranthus tricolor. J. Agric. Food Chem. 2004, 52, 6939-6943. [CrossRef] 
9. Rahmatullah, M.; Hosain, M.; Rahman, S.; Akter, M.; Rahman, F.; Rehana, F.; Munmun, M.; Kalpana, M.A. Antihyperglycaemic and antinociceptive activity evaluation of methanolic extract of whole plant of Amaranthus Tricolour L. (Amaranthaceae). Afr. J. Tradit. Complementary Altern. Med. 2013, 10, 408-411.

10. Khandaker, L.; Ali, M.B.; Oba, S. Total polyphenol and antioxidant activity of red amaranth (Amaranthus tricolor L.) as affected by different sunlight level. J. Jpn. Soc. Hortic. Sci. 2008, 77, 395-401. [CrossRef]

11. Alam, S.; Krupanidhi, K.; Sambasiva Rao, K.R.S. Evaluation of in-vitro antioxidant activity of Amaranthus tricolor Linn. Asian J. Pharmacol. Toxicol. 2013, 1, 12-16.

12. Khanam, U.K.S.; Oba, S. Bioactive substances in leaves of two amaranth species, Amaranthus tricolor and A. hypochondriacus. Can. J. Plant Sci. 2013, 93, 47-58. [CrossRef]

13. Al-Dosari, M.S. The effectiveness of ethanolic extract of Amaranthus tricolor L.: A natural hepatoprotective agent. Am. J. Chin. Med. 2010, 38, 1051-1064. [CrossRef]

14. Yuniarto, A.; Putri, A.Z.; Selifiana, N.; Adnyana, I.K. Preventive effect of ethanol extract of red spinach (Amaranthus tricolor L.) on diet-induced obese zebrafish. Eur. J. Med. Plants. 2020, 31, 27-32. [CrossRef]

15. Pulipati, S.; Babu, P.S.; Narasu, M.L. Quantitative determination of tannin content and evaluation of antibacterial activity of Amaranthus tricolor (L). Int. J. Biol. Pharm. Res. 2014, 5, 623-626.

16. Oh, Y.S.; Lee, S.H. Isolation and identification of antimicrobial compound from Amarnathu lividus. Microbiol. Biotechnol. Lett. 2005, 33, 123-129.

17. Abd, A.S.M. Screening of selected Malaysian plants against several food borne pathogen bacteria. Int. Food. Res. J. 2011, 18, 1195-1201.

18. Lina, A.; Rivillas, A.; Manuel, S.G. Isolation and biochemical characterization of an antifungal peptide from Amaranthus hypochondriacus seeds. J. Agric. Food Chem. 2007, 55, 156-161.

19. Lyapkova, N.S.; Loskutova, N.A.; Maisuryan, A.N.; Mazin, V.V.; Korableva, N.P.; Platonova, T.A.; Ladyzhenskaya, E.P.; Evsyunina, A.S. Transformed potato plants carrying the gene of the antifungal peptide of Amaranthus caudatus. Appl. Biochem. Microbiol. 2001, 37, 349-354. [CrossRef]

20. Xia, R.Z.; Liu, S.Q.; Xie, Y.; Zhang, Y.; Wang, C.; Yin, W.; Liao, X.L. Antibacterial activity of Amaranthus tricolor extracts against five phytopathogenic bacteria. Egypt. J. Biol. Pest. Control 2016, 26, 157-162.

21. Chen, Y.S.; Lin, X.Y.; Zhong, L.J.; Xie, J.M.; Zhang, Y.H. Chemical constituents of Vitex trifolia L. Nat. Prod. Res. Dev. 2011, 23, 1011-1048.

22. Maulidiani; Shaari, K.; Paetz, C.; Stanslas, J.; Abas, F.; Lajis, N.H. Naturally occurring labdane diterpene and benzofuran from Globba pendula. Nat. Prod. Commun. 2009, 4, 1031. [CrossRef] [PubMed]

23. Gahukar, R.T. Evaluation of plant-derived products against pests and diseases of medicinal plants: A review. Crop Prot. 2012, 42, 202-209. [CrossRef]

24. Rousset, B. Antithyroid effect of a food or drug preservative: 4-hydroxybenzoic acid methyl ester. Experientia 1981, 37, 177-178. [CrossRef] [PubMed]

25. Seidel, C.; Schnekenburger, M.; Dicato, M.; Diederich, M. Antiproliferative and proapoptotic activities of 4-hydroxybenzoic acid-based inhibitors of histone deacetylases. Cancer Lett. 2014, 343, 134-146. [CrossRef] [PubMed]

26. Kitade, Y.; Hashimoto, R.; Suda, M.; Hiraga, K.; Inui, M. Production of 4-hydroxybenzoic acid by an aerobic growth-arrested bioprocess using metabolically engineered Corynebacterium glutamicum. Appl. Environ. Microbiol. 2018, 84, e02587-17. [CrossRef] [PubMed]

27. Zhu, C.X.; Jiang, X.L.; Sun, D.Y. Zhongshengmycin, a New Agro-antibiotics. Fine Spec. Chem. 2002, 16, 14-17.

28. Chen, X.Y.; Zhao, C.H.; Liu, S.; Liang, J.H. Study on antibacterial activity of allicin in vitro. J. Shenyang Agric. Univ. 2008, $1,108-110$

29. Jonkers, D.; Van, D.B.E.; Van, D.I.; Thijs, C.; Dorant, E.; Hageman, G.; Stobberingh, E. Antibacterial effect of garlic and omeprazole on Helicobacter pylori. J. Antimicrob. Chemother. 1999, 43, 837-839. [CrossRef]

30. Ferreira, G.R.S.; de Santana Brito, S.B.J.; Procopio, T.F.; Santos, N.D.L.; Cardoso de Limab, B.J.R.; Coelho, L.C.B.B.; Navarro, D.M.A.F.; Paiva, P.M.G.; Soares, T.; Moura, M.C.; et al. Antimicrobial potential of Alpinia purpurata lectin (ApuL): Growth inhibitory action, synergistic effects in combination with antibiotics, and antibiofilm activity. Microb. Pathog. 2018, 124, 152-162. [CrossRef] [PubMed]

31. Tremaroli, V.; Workentine, M.L.; Weljie, A.M.; Vogel, H.J.; Ceri, H.; Viti, C.; Tatti, E.; Zhang, P.; Hynes, A.P.; Turner, R.J.; et al. Metabolomic investigation of the bacterial response to a metal challenge. Appl. Environ. Microbiol. 2009, 75, 719-728. [CrossRef] [PubMed]

32. Aliferis, K.A.; Jabaji, S. Metabolomics-a robust bioanalytical approach for the discovery of the modes-of-action of pesticides: A review. Pestic. Biochem. Physiol. 2011, 100, 105-117. [CrossRef]

33. Fleck, C.B.; SchBel, F.; Brock, M. Nutrient acquisition by pathogenic fungi: Nutrient availability, pathway regulation, and differences in substrate utilization. Int. J. Med. Microbiol. 2011, 301, 400-407. [CrossRef] [PubMed]

34. Rajam, B.; Rajam, M.V. Inhibition of polyamine biosynthesis and growth in plant pathogenic fungi in vitro. Mycopathologia 1996, 133, 95-103. [CrossRef]

35. Yang, J.; Wang, Y.; Wei, P.H. The development of clinical and pharmacological study on S Adenosyl L methionine. Prog. Pharm. Sci. 2001, 25, 164-167. 
36. Chen, X.; Zhao, Y.S.; Dong, Y.; Su, P. Metabolomic analysis of Mn (2+) effect on the metabolic pathways in lactobacillus plantarum. J. Chin. Inst. Food Sci. Technol. 2019, 19, 258-265.

37. Ricke, S. Perspectives on the use of organic acids and short chain fatty acids as antimicrobials. Poultry. Sci. 2003, 82, 632-639. [CrossRef] [PubMed]

38. Zhang, Q.L.; Li, W.; Liu, B.; Yan, Y.Q. Research progress on fatty acids and apoptosis. J. Northeast Agric. Univ. $2006,4,539-545$.

39. Wang, J.Q.; Zhao, G.X.; Liu, Y.; Gao, J.Y.; Xie, Q.; Han, Y.P.; Li, Y.Z. Metabonomic analysis of Escherichia coli carried on “Shijian 10". Microbiol. China 2019, 46, 233-240.

40. Lan, W.Q.; Xie, J.; Hou, W.F.; Li, D.W. Study on antibacterial activity and action mechanism of compound biological preservative against Staphylococcus squirrel. Nat. Prod. Res. Dev. 2012, 6, 741-746.

41. Zhou, L.; Yun, B.Y.; Wang, Y.J.; Xie, M.J. Antibacterial mechanism of emodin on Staphylococcus aureus. Chin. J. Biochem. Mol. Biol. 2011, 12, 1156-1160.

42. He, L.Y. Study on the response mechanism of nitrobacteria antioxidant enzyme system under low temperature shock. Southwest Jiaotong Univ. 2013, 12-13.

43. Du, X.T.; Song, X.; Liu, X.X.; Xia, Y.J.; Ai, L.Z.; Xiong, Z.Q. Research progress on transcription regulators of bacterial extracellular polysaccharide biosynthesis. Microbiol. China 2021, 48, 573-581.

44. Keppler, L.D.; Baker, C.J. O2 initiated lipid peroxidation in a bacteria-induced hypersensitive reaction in tobacco cell suspensions Phytopathology 1989, 79, 555-562. [CrossRef]

45. Chai, H.B.; Doke, N. Activation of the potential of potato leaf tissue to react hypersensitive to Phytophthora infestans cytospora germination fluid and the enhancement of this potential by calciumions. Physiol. Mol. Plant Pathol. 1987, 30, 27. [CrossRef]

46. Chigrin, V.V. Oxidative, Lipolytie and Protective enzymes in the leaves of rust resistant and susce-ptible Plants of wheat. Soviet Plant Physiol. 1988, 35, 921-929.

47. Zhang, Y.; Su, P.; Wang, C.; Liao, X.L. Identification of a novel broad-spectrum anti-fungal strain of Pseudomonas aeruginosa (SU8) and effect of its crude metabolites against Rhizoctonia solani and Pyricularia oryzae. Egypt. J. Biol. Pest. Control 2015, 25, 295-304.

48. Bharate, S.B.; Khan, S.I.; Yunus, N.; Chauthe, S.K.; Jacob, M.P.; Tekwani, B.L.; Khan, I.A.; Singh, I.P. Antiprotozoal and antimicrobial activities of O-alkylated and formylated acylphloroglucinols. Bioorg. Med. Chem. 2007, 15, 87-96. [CrossRef]

49. Olajuyigbe, O.O.; Olajuyigbe, A.A.; Afolayan, A.J. Ultrastructure and X-ray microanalysis of the antibacterial effects of stem bark ethanol extract of Acacia mearnsii de wild against some selected bacteria. J. Pure. Appl. Microbiol. 2018, 12, 2217-2228. [CrossRef]

50. Chen, W.; Gong, L.; Guo, Z.; Wang, W.S.; Zhang, H.L.; Liu, X.Q.; Yu, S.B.; Xiong, L.Z.; Luo, J. A novel integrated method for large-scale detection, identification, and quantification of widely targeted metabolites: Application in the study of rice metabolomics. Mol. Plant. 2013, 6, 1769-1780. [CrossRef]

51. Wei, C.Y. Inhibition mechanism of gallic acid against rice bacterial streak disease and its control effect on the disease. Guangxi Univ. 2016, 10-11.

52. Chavan, P.S.; Tupe, S.G. Antifungal activity and mechanism of action of carvacrol and thymol against vineyard and wine spoilage yeasts. Food Control 2014, 46, 115-120. [CrossRef]

53. Huang, Q.C.; Zhou, M.G.; Ye, Z.Y. Effect of amicarthiazol to the cell Xanthomonas citri. J. Nanjing Agric. Univ. 2001, 24, 23-26. 